\title{
ASSESSMENT AND IDENTIFICATION OF THREE TYPES OF DIFFICULT SOILS
}

\author{
Tahar AYADAT
}

Prince Mohammad Bin Fahd University, Al-Khobar, Saudi Arabia

*Corresponding author's e-mail: tayadat@pmu.edu.sa

\begin{tabular}{l}
\hline ARTICLE INFO \\
\hline Article history: \\
Received 5 January 2021 \\
Accepted 6 April 2021 \\
Available online 21 April 2021
\end{tabular}

Keywords:

Identification

Prediction

Collapsible soil

Swelling soil

Liquefaction

Difficult soils

\begin{abstract}
The soil engineer needs to be able to readily identify difficult or problematic soils and to determine the amount of settlement that may occur. This paper deals with the assessment and identification of three types of difficult soils: collapsible soils, swelling soils, and liquefiable soils. In the first instance, the study investigates the effect of some soil properties on wetting-induced collapse strain and the swelling potential of soils. Also, two new methods for predicting soil collapse and swelling potential are developed. The proposed relationships correlate between collapse strain and swelling potential and some soil parameters which are believed to govern soil collapse and swelling. Validation of these two relationships with some data reported in literature is also examined. Furthermore, the paper describes the different steps suggested in a new procedure for soil liquefaction assessment. The procedure was presented in the form of an evaluation guide. In addition, a relationship was suggested for computing the potential for liquefaction. An application of the proposed procedure to a practical case is included in order to validate and illustrate the different steps to be followed in the suggested evaluation procedure.
\end{abstract}

\section{INTRODUCTION AND BACKGROUND}

Difficult soils are those that make the construction of foundation extremely difficult. Due to the increase of land development all over the world, the need to deal with difficult soils has become essential. The best-known difficult or problematic soils are collapsible soils, expansive soils, liquefiable soils, sabkha soils, compressible soils, peat, etc. This investigation is concerned with three types of difficult soils: collapsible soils, expansive soils, and liquefiable soils. Expansion, liquefaction, and collapsibility of soils give rise to many geotechnical difficulties, including inadequate bearing capacity, the potential for unacceptable settlements, and slope instability. In the following, some details about these three different soils are summarized.

Collapsible soils are defined as any unsaturated soils that go through a radical re-arrangement of particles and a great volume decrease upon wetting, with or without additional loading. The most extensive deposits of collapsible soil are aeolian or wind-deposited sands and silts (loess). However, in addition to these deposits, there is a wide variety of other types of deposits which have been identified as having an unstable structure. These are in alluvial flood plains, fans and mudflows, colluvial deposits, residual soils, volcanic tuffs, and man-made fill.

Most of the work carried out on the parameters governing the collapse of partially saturated soils have focused on the initial dry density, moisture content, degree of saturation, and overburden pressure. The influence of these factors on the amount of collapse has been investigated by several researchers. Most of them have agreed that for a given moisture content, the amount of collapse increases with the dry density. Meanwhile, for any given dry density, the magnitude of collapse decreases with increasing moisture content, and there is a critical moisture content above which no collapse occurs (e.g., Booth, 1975; Lefebvre et al., 1989; Lawton, 1989). At a given dry density, the overburden stress level at which the maximum amount of collapse takes place varies inversely with the compaction water content (e.g., Booth, 1975; Cox, 1978; Lawton, 1989). Moreover, there is a critical degree of saturation beyond which the soils do not appear to be susceptible to collapse. Booth (1975, 1977) and Geneshan (1982) proposed a critical degree of saturation of 50-60\%. Markin (1969) and Prusza and Choudry (1979) suggested slightly higher values, between $60 \%$ and $65 \%$.

For the identification of collapsible soils, different criteria have been adopted or established by different investigators. Most of the criteria reported in the literature before 2010 were reviewed by Ayadat et al. (2011). Many other research works were carried out in the last decade to investigate the parameters affecting soil collapse and to develop empirical equations in order to correlate the amount of soil collapse to soil properties (e.g., Lommler and Bandini, 2015; Li et al., 2016; Bigdeli and Siddiqua, 2016; Ping 
and Vanapalli, 2018; Bigdeli, 2018). However, the proposed correlations for soil collapse consider only the interrelation between traditional factors such as dry density, moisture content, or degree of saturation. These methods do not take into account the influence of the soil particle distribution, clay content, and chemical composition of assessed soils. It was observed that the phenomenon of suffusion (grain-movement in a ground layer from one horizon to another during wetting up) is one of the main causes of collapse (Ayadat et al., 1998). Furthermore, it is believed that a more reliable and trustworthy prediction method should include most of the parameters governing soil collapse, such as dry unit weight, degree of saturation, clay content, soil particle size distribution or equivalent diameter, applied pressure, and chemical composition of soil.

Expansive soils are defined as any unsaturated soils or rocks that have the ability to shrink or expand when a change in their environment and moisture conditions occurs. Expansive soil is a worldwide problem, causing more damage to structures, particularly light buildings and pavement, than any other natural hazard, including earthquakes and floods.

The origin of expansive soils is related to a complex combination of conditions and processes that result in the formation of clay minerals having a particular makeup which, when in contact with water, will expand. The conditions or processes that determine the clay mineralogy include the composition of the parent material and the degree of physical and chemical weathering to which the materials are subjected. The areas most susceptible to expansive clay activity have the following climatic characteristics: very high evaporation or evapotranspiration rates during some time of the year, sufficient rainfall to wet the soil thoroughly to depth of at least $76 \mathrm{~cm}$, and a long dry period followed by a period of wet weather.

The amount of expansion in a soil depends on many factors. The most influential factors are the mineralogical composition of the soil particles, soil and pore water chemistry, soil suction, soil structure and fabric, initial moisture content, initial dry density, thickness of the expansive soil layer, depth of the active zone, permeability, state of stress, and climate. Experimental studies on expansive soils show that the percentage of the expansion of a soil increases proportionally to its unit weight, limit of liquidity, clay content, indexes of liquidity, plasticity, and shrinkage, as well as its pressure of preconsolidation (Seed et al., 1962; Ranganatham and Satyanarayana, 1965; Nayak and Christensen, 1971; Vijayvergiya and Gazzhaly, 1973). It was also reported that swelling of an expansive soil is inversely proportional to its natural moisture content. The highest percentages of expansion observed and reported in the literature are on the order of $160 \%$ (Komornik and David, 1969).
Determination of expansive soils and quantification of their swelling potential and the pressure caused by their expansion are essential in geotechnical engineering. Therefore, it is necessary to develop models to predict the swelling pressure and swelling potential of expansive soils. Considerable studies have been done in an attempt to evaluate the expansion behavior of plastic clays. Researchers have given greater attention to empirical investigations of the expansion behavior of compacted and natural soils (Holtz and Gibbs, 1956). In general, numerous experimental techniques have been suggested to determine and classify the swelling characteristics of expansive soils. Interpretations used to qualify expansive clays are not only dissimilar but also based either on soil index properties or results taken directly from swelling determination tests. Many criteria have been proposed to identify and characterize expansive soil, such as the liquid limit, plasticity index, shrinkages limit, free swell index, percent free swell, and modified free swell index (e.g., Derriche and Kebaili, 1998; Muntohar, 2000; Erzin et al., 2004; Lin and Cerato, 2011; Israr et al., 2014; Forouzan, 2016; Diana et al., 2018). However, these methods do not take into consideration the influence of effective stress at sampling depth, shrinkage index, and liquidity index of the evaluated soils. Moreover, as stated previously, a more reliable prediction method should include most of the parameters which are believed to govern swelling potential, such as dry unit weight, moisture content, clay content, plasticity index, liquidity index, shrinkage index, and effective stress at sampling depth.

Soil liquefaction is a geological phenomenon which is generally sudden and severe, albeit temporary, whereby a water-saturated soil loses part or all of its bearing capacity, leading to the submergence of heavy structures in the ground. Earthquake waves cause pore water pressure to increase in a saturated sandy soil and the sand grains to lose contact with each other, leading the sediment to lose its shearing strength and behave like a liquid for a short time (JSSMFE, 1985). When liquefaction occurs, the ability of a soil deposit to support the foundations of buildings and bridges is reduced, causing turnover (loss of bearing capacity). Quite often, geotechnical engineers have the challenge of dealing with difficult soils such as loose granular soil susceptible to liquefaction. Today, valuable experience has been achieved in classifying and testing this type of soil.

The factors influencing liquefaction can be grouped into three categories, namely, soil properties (unit weight, particle size distribution, fine or clay content, plasticity index, relative density, degree of saturation, structure of skeleton, shear modulus; Huang, 2019), geological conditions (water table, geological age, overconsolidation ratio, initial static shear strength, boundary conditions against seepage, 
drainage conditions), and earth motions (magnitude of earthquake, horizontal acceleration, number of cycles or duration, direction of shearing).

Given the speed, suddenness, and unpredictability of this phenomenon, soil liquefaction may cause partial or total destruction of buildings and even loss of lives. In addition, it may cause the penetration of constructions into the ground. The only prevention technique and protection (in the case of liquefiable soil) is adequate identification of soils, followed by a suitable foundation design for structures and other facilities. There are various criteria for determining a soil's susceptibility to liquefaction, including historical, geological, compositional, and soil condition criteria (e.g., Kramer, 1996). Various methods for identifying soil liquefaction from a relatively simple index have been suggested by several workers in the field. Different methods available in literature for the determination of soil liquefaction susceptibility, based on a standard penetration test (SPT), have been suggested (e.g., Seed and Idriss, 1967; Seed and Idriss, 1971, Seed and Peacock, 1971; Seed et al., 1983; Seed et al., 1984; Seed et al., 1997; Youd et al., 2001). These methods, which remain an important means for evaluating soil liquefaction, have been revised by many researchers due to some shortcomings, such as the variable nature of the SPT (e.g., Skempton, 1986; Stark and Olson, 1995, Blake, 1997; Rauch, 1998). Moreover, many other methods have been developed for soil liquefaction assessment, including geophysical methods (e.g., Tokimatsu and Uchida, 1990; Robertson et al., 1992), the cone penetration test (CPT)-based method (e.g., Robertson and Campanella, 1985; Olsen, 1997; Robertson and Wride, 1998; Baziar and Esna-Ashari, 2004; Esna-Ashori and Baziar, 2004; Mosset al., 2006), strain energy concept (e.g., Baziar and Jafarian, 2007), artificial neural network (ANN) methods based on CPT data (e.g., Goh, 1996 and Baziar and Nilipour, 2003), capacity energy (e.g., Baziar and Jafarian, 2007), and the least square support vector machine (LSSVM) based on CPT data (e.g., Samui and Karthikeyan, 2013). However, a simple procedure for soil liquefaction assessment is consistently convenient in any geotechnical project. Furthermore, computing the potential for liquefaction is crucial in any soil investigation.

This paper deals with the assessment and identification of three types of difficult soils. In the first instance, the study investigates the effect of some soil properties on wetting-induced collapse strain and the swelling potential of soils. Also, two new methods for predicting soil collapse and swelling potential are developed. The proposed relationships correlate between collapse strain and swelling potential and some soil parameters which are believed to govern soil collapse and swelling. Validation of these two relationships with some data reported in literature is considered. Furthermore, the paper contains a description of the different steps suggested in a new procedure for soil liquefaction assessment. The procedure is presented in the form of an evaluation guide. In addition, a relationship is suggested for computing the potential for liquefaction. An application of the proposed procedure to a practical case is included in order to validate and illustrate the different steps to be followed in the suggested evaluation procedure.

\section{METHODOLOGY}

For the assessment of collapsible and expansive soils, an experimental program was carried out using the consolidation test. On the other hand, the evaluation of soils' liquefaction susceptibility was based on the analysis of many liquefaction cases observed in the field and in laboratory works, and according to the results of a large number of verifications performed by the author on different soils.

For collapsible soils, a series of tests were performed on reconstituted soil specimens. The samples were prepared carefully in order to duplicate the soils encountered in a collapsible area in the region of Biskra. Due to soil disturbance and the difficulty of trimming a sample from soil cores extracted by drilling, the tests were conducted on reconstituted samples. Biskra is located in southeastern Algeria, about $400 \mathrm{~km}$ from Algiers. It has a desert climate, and throughout the year, rain is practically non-existent. According to the Köppen-Geiger classification, the climate is BWh. Biskra has an average annual temperature of $21.8^{\circ} \mathrm{C}$ and an average precipitation of $141 \mathrm{~mm}$.

Drillings were carried out using a drilling machine type Simco assembled on trailer and equipped for ground sampling. Boreholes reached depths between $3.0 \mathrm{~m}$ and $11.5 \mathrm{~m}$. During the drilling operation, disturbed samples of soil were obtained at interval of 0.6 to $1.5 \mathrm{~m}$ depth. A standard 'B" split spoon, with an inside diameter of $38 \mathrm{~mm}$, was used to perform the standard penetration test (SPT) as per the specification D1586/D1586M-18. In order to increase the soil recovery following a poor recuperation of sample, a " $N$ '" split spoon with an inside diameter of $50 \mathrm{~mm}$ was used (Photos 1 and 2).

Ten samples were prepared for testing in the oedometer test machine. The samples were reconstituted from the soil cores extracted from different boreholes. The particle size distributions, physical properties, and mineralogical compositions of the prepared soils are presented in Figure 1 and Table 1.

All the tests were performed in a conventional oedometer cell of $50 \mathrm{~mm}$ diameter and $20 \mathrm{~mm}$ thickness. The samples were inundated from the bottom center of the cell through a porous stone of $50 \mathrm{~mm}$ diameter and $5 \mathrm{~mm}$ thickness. The inundation was conducted by filling the space surrounding the soil specimen by water so that the distance between the cell top and the water-free surface was kept constant and did not exceed a few millimeters. The samples were 


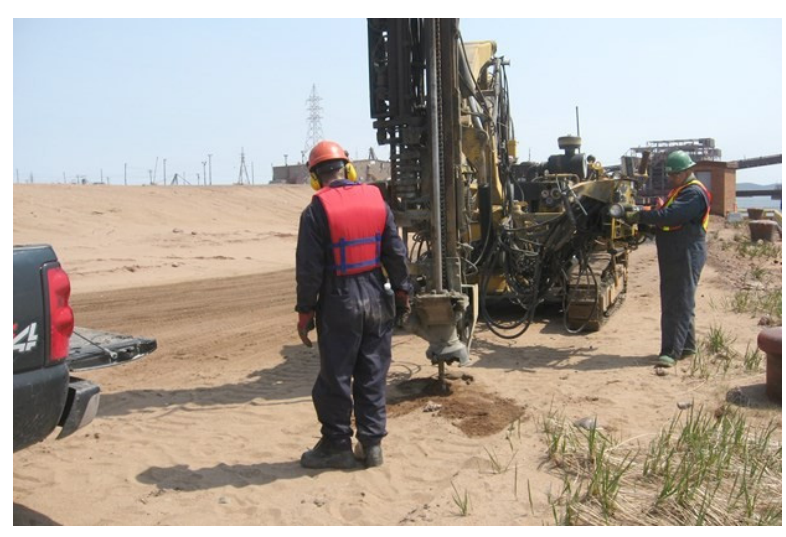

Photo 1 Field-drilling works for collapsible soils.

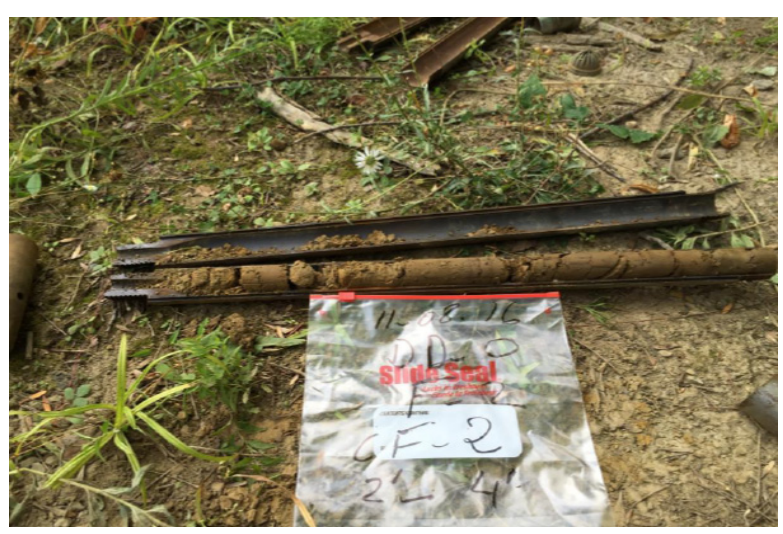

Photo 2 Field sampling of collapsible soils.

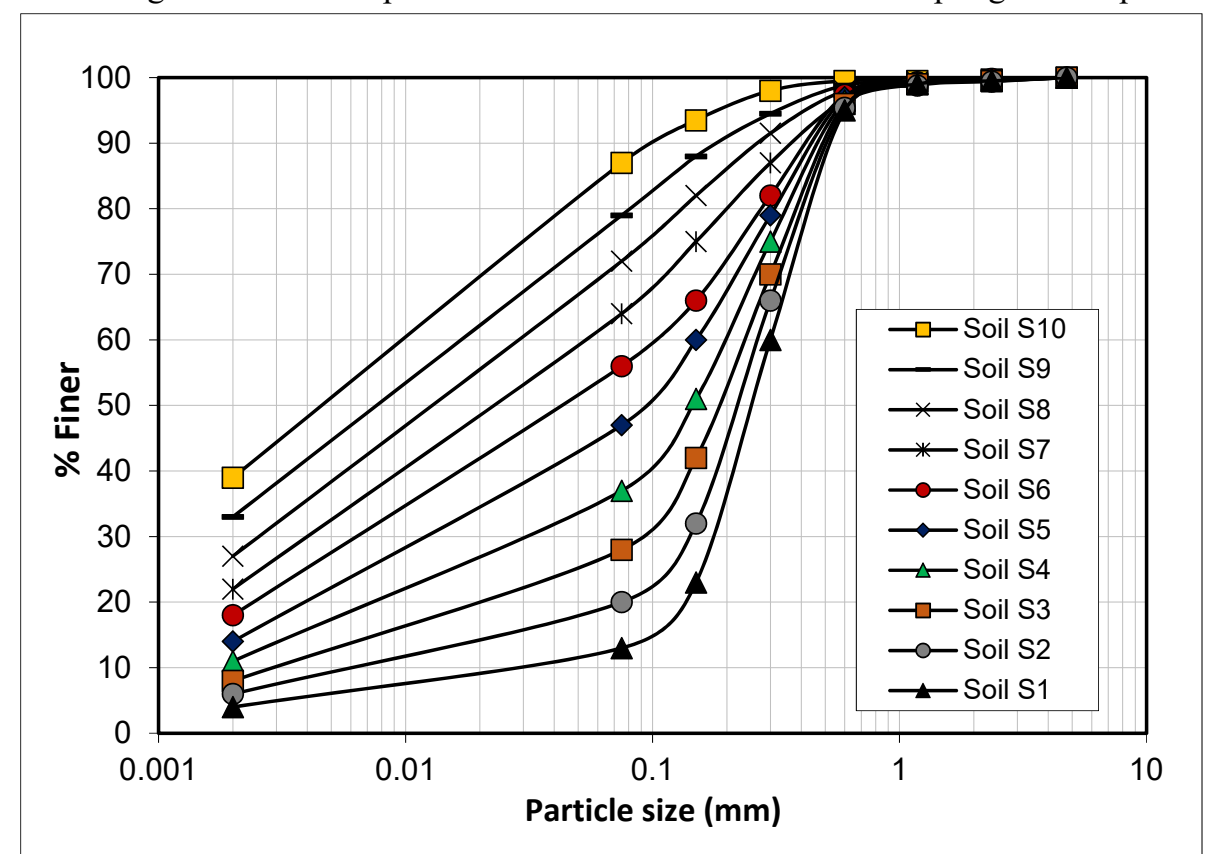

Fig. 1 Particle size distribution of the different soils tested.

Table 1 Characteristics of the different soils tested.

\begin{tabular}{lcccccc}
\hline Soils & $\begin{array}{c}\text { Equivalent } \\
\text { Diameter }(\mathrm{mm})\end{array}$ & $\begin{array}{c}\text { Dry Unit Weight, } \\
\gamma \mathrm{d}\left(\mathrm{kN} / \mathrm{m}^{3}\right)\end{array}$ & $\begin{array}{c}\text { Percentage of } \\
\text { Particles }<2 \mu \mathrm{m}(\%)\end{array}$ & $\begin{array}{c}\text { Degree of } \\
\text { Saturation }(\%)\end{array}$ & $\begin{array}{c}\mathrm{CaO}(\%) \\
\mathrm{Al} \text { (\%3 } \\
(\%)\end{array}$ \\
\hline S1 & 0.0267 & 17.52 & 4 & 62.67 & 45.46 & 5.54 \\
S2 & 0.0239 & 17.0 & 6 & 49.55 & 47.5 & 6.32 \\
S3 & 0.0222 & 16.21 & 8 & 37.98 & 49.1 & 6.97 \\
S4 & 0.0210 & 15.86 & 11 & 27.65 & 50.33 & 7.48 \\
S5 & 0.0190 & 15.12 & 14 & 15.12 & 53.18 & 8.33 \\
S6 & 0.0170 & 15.0 & 18 & 9.45 & 54.46 & 8.90 \\
S7 & 0.0147 & 15.51 & 22 & 19.76 & 56.34 & 10.01 \\
S8 & 0.0135 & 16.04 & 27 & 33.22 & 57.47 & 10.45 \\
S9 & 0.0118 & 16.55 & 33 & 45.82 & 58.91 & 11.31 \\
S10 & 0.0089 & 17.18 & 49 & 54.67 & 60.66 & 12.38 \\
\hline
\end{tabular}

placed in the oedometer cell, and the procedure followed for testing was that used by Ayadat and Hanna (2007a). The soil was placed in the oedometer cell in two layers by compaction using an impact hammer similar to that used by Ayadat and Hanna (2007b). Conventional consolidation-collapse tests at natural moisture content were conducted; the load on top of the soil sample was applied incrementally to reach the required testing load of $200 \mathrm{kPa}$ (ASTM $\mathrm{D}-5333$, 2003). At the end of this loading, the specimen was fully saturated by inundating the cell with distilled water and leaving it for 24 hours; then, the consolidation test was performed up to the maximum loading limit. The vertical displacement of 
soil specimen was measured by a dial gage mounted on the top of the specimen. The most common method to calculate the collapse potential of soil is proposed in ASTM D-5333 (2003). It is worth mentioning herein that Jennings and Knight (1975) were the first to use a vertical total stress of $200 \mathrm{kPa}$, at which the samples' saturation was carried out. Moreover, in order to investigate the influence of the applied stress $(\sigma)$ on the wetting-induced collapse strain, a series of oedometer tests were carried out on soils S2, S4, S6, and S7. Five different stresses were considered, namely $50,100,200,300$, and $400 \mathrm{kPa}$, in addition to the conventional oedometer tests at initial moisture content and at saturation. The wetting-induced collapse strain was calculated using the following equation:

$\varepsilon_{c}=\frac{\Delta e_{c}}{1+e_{o}}$

where:

$\Delta e_{c}=$ change in the void ratio due to inundation,

$e_{o} \quad=$ initial void ratio.

For expansive soils, a series of tests were performed on undisturbed soils specimens. The samples were trimmed from sample cores extracted from thin-wall tube (Shelby) samplers. The Shelby tube is commonly used to obtain relatively undisturbed samples of cohesive soils for consolidation testing (D1587/D1587M-15). The tested samples were seized from thin-wall tube samplers retrieved from a series of boreholes undertaken in the region of M'Sila. This region is also located in southeastern Algeria, about $300 \mathrm{~km}$ from Algiers. It is located at $483 \mathrm{~m}$ of altitude. A steppe climate is present in M'Sila, and throughout the year there is little rainfall. The climate map of Köppen-Geiger classifies the climate there as BSk type. M'Sila has an average annual temperature of $15.8^{\circ} \mathrm{C}$ and an average annual precipitation of $229 \mathrm{~mm}$.

Expansive clays of the region of M'Sila are classified as low-to high-plastic clays ( $\mathrm{CL}$ to $\mathrm{CH}$ ), overconsolidated, and having very low sensitivity. They belong to subclass A4 and are considered as low fragmentary (Khemissa et al., 2008; Mahamedi and Khemissa, 2013, 2014; Khemissa and Mahamedi, 2014).

Laboratory tests to measure the magnitude of one-dimensional wetting-induced free swell of unsaturated undisturbed soils were conducted by simple oedometer test apparatus according to ASTM D4546-90, Method A. Twelve specimens were tested; despite their common origin, they had relatively different physical and chemical properties. The clay specimen was placed at natural moisture content in the oedometer cell under a vertical pressure of $7 \mathrm{kPa}$. This pressure was adopted only to avoid any disturbance of the soil sample. The specimen was then flooded (similarly to the case of collapsible soils) and left to swell freely until the end of the swelling process. The wetting-induced free swell was calculated using the following equation:
$\varepsilon_{S}=\frac{\Delta H}{H_{O}}$

where:

$\Delta H=$ change in the specimen height due to inundation,

$H_{o} \quad$ = initial height of the soil specimen.

It is worthy to note that the effects of sampling disturbance in soils and the consequences of different sample quality on the representativeness of soil parameters are well established. Safe and cost-effective geotechnical design is critically dependent on the representativeness of soil parameters, as these affect the accuracy of the associated predictions. However, in the present investigation tests were conducted on intact undisturbed soil specimens for the case of swelling and liquefiable soils. Whereas, for collapsible soils, they were performed on laboratory reconstituted or remolded samples. The reconstituted soil specimens were carefully prepared in the consolidation ring from disturbed soil cores. The soil was compacted into the consolidation ring, making sure that the soil was tightly packed into the ring and there were no sampling disturbance.

For the case of liquefiable soils, as indicated previously, the evaluation of soils' liquefaction susceptibility was based on the analysis of many liquefaction cases observed in the field and in laboratory works, and according to the results of a large number of verifications performed by the author on different soils. All the verifications were conducted using the method proposed by Prakash (1981) and the method developed by the NCEER working group (NCEER, 1997). For this reason, these two methods are summarized herein. These two methods were selected among many other approaches because of their simplicity and because they are prevalently used.

In the method proposed by Prakash (1981), the principle is to calculate the shear stress induced by an earthquake $\left(\tau_{a v}\right)$ and compare it to the critical soil shear strength $\left(\tau_{c r}\right)$. If $\tau_{a v}$ is greater than or equal to $\tau_{c r}$ at a given depth, the soil is potentially liquefiable (Youd et al., 2001; Seed et al., 2003). The shear stress induced by earthquake $\left(\tau_{a v}\right)$ in the granular deposit is given as (Prakash, 1981):

$\tau_{a v} \approx 0.65 \times \frac{\gamma h}{g} a_{\max } \times r_{d}$

where:

$\tau_{a v}=$ the average (equivalent) shear stress induced by earthquake,

$a_{\max }=$ maximum acceleration at the ground surface (peak ground acceleration, PGA),

$r_{d}=$ factor of correction for deformable body/rigid body,

$0.65=$ mean equivalent shear stress $\left(\tau_{a v}\right) /$ maximum shear stress,

$\gamma=$ unit weight of soil, in $\mathrm{kN} / \mathrm{m}^{3}$ ( $\gamma_{\text {sat }}$ below ground-water level). 


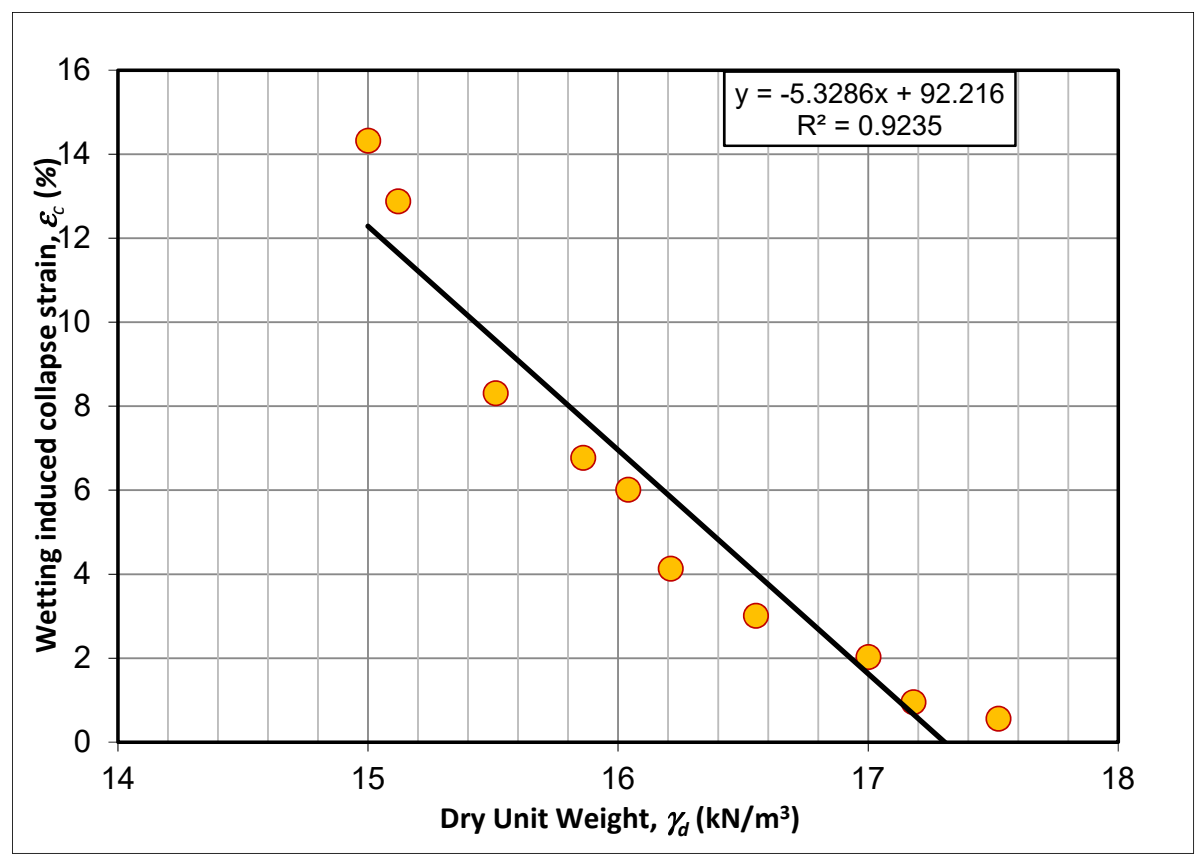

Fig. 2 Variation of wetting-induced collapse strain versus dry unit weight.

The critical shear strength of soil $\left(\tau_{a v}\right)$ can be estimated using the following equation (Prakash, 1981):

$\left(\frac{\tau}{\sigma_{0}^{\prime}}\right)_{t D_{r}} \cong\left(\frac{\sigma_{d c}}{2 \sigma_{a}}\right)_{t 50} c_{r} \frac{D_{r}}{50}$

where:

$D_{r} \quad=$ relative density,

$c_{r} \quad=$ correction factor (Seed \& Idriss, 1971),

$\sigma_{0}^{\prime} \quad=$ effective stress $\left(\gamma^{\prime} H\right.$, with $\left.\gamma^{\prime}=\gamma_{s a t}-\gamma_{w}\right)$,

$\sigma_{d c} \quad=$ cyclic deviator stress,

$\sigma_{a} \quad=$ consolidation pressure,

$\sigma_{d c} / 2 \sigma_{a}=$ determined empirically (Seed and Idriss, 1971),

$\mathrm{D}_{50} \quad=$ mean particle size (taken from particle size distribution).

The method developed by the NCEER working group (NCEER, 1997), as modified by Seed et al. (2003), is addressed in the form of a chart (Figure A1, Appendix A). In this chart, boundaries separating liquefiable and non-liquefiable soils are suggested for different soil fine particle contents. The chart is based mainly on a comparison between the cyclic stress ratio $(C S R)$ and the modified SPT N-value $\left(N_{1}\right)_{60}$. The cyclic stress ratio can be computed using the following equation (Equation 5, NCEER, 1997):

$C S R=0.65\left(\frac{a_{\max }}{g}\right)\left(\frac{\sigma_{v o}}{\sigma_{v o}^{\prime}}\right) r_{d}$

where:

$a_{\max }=$ peak horizontal acceleration at ground surface generated by earthquake,

$g \quad=$ acceleration of gravity,

$\sigma_{v o}$ and $\sigma_{v o}^{\prime}=$ total and effective stresses,

$r_{d}=1.0-0.00765 \times z \quad$ for $z \leq 9.16 \mathrm{~m}$, $r_{d}=1.174-0.0267 \times z$

$r_{d}=0.744-0.008 \times z$

$r_{d}=0.50$

for $9.15 \mathrm{~m}<z \leq 23 \mathrm{~m}$, for $23<z \leq 30 \mathrm{~m}$, for $z>30 \mathrm{~m}$.

$\left(N_{1}\right)_{60}$ is the SPT $N$-value corrected for field procedures and the apparatus (effective overburden stress and energy, equipment and procedure factors). Recommended corrections for this modified standard penetration test $\left(N_{1}\right)_{60}$ can be taken from Robertson and Wride (1998), as modified from Skempton (1986).

\section{TEST RESULTS AND ANALYSIS}

The aim of this investigation is the assessment and identification of three types of difficult soils, namely collapsible soils, expansive soils, and liquefiable soils. For this purpose, a parametric study was conducted in order to investigate the influence of some soil parameters on wetting-induced collapse strain, wetting-induced free swelling, and soil liquefaction susceptibility.

The parameters considered for collapsible soils are dry unit weight, degree of saturation, clay content, equivalent diameter, applied pressure prior to wetting-up, and chemical composition. The variation of collapse strain with dry unit weight is presented in Figure 2. It is clear from this figure that wettinginduced collapse strain decreases when dry unit weight increases. The collapse is inversely proportional to the dry unit weight, and the relationship can be considered as linear, with a coefficient of correlation of $R=0.965$. The relationship can be presented by the following equation:

$\varepsilon_{c(1)}=-5.33 \times \gamma_{d}+92.2$ 


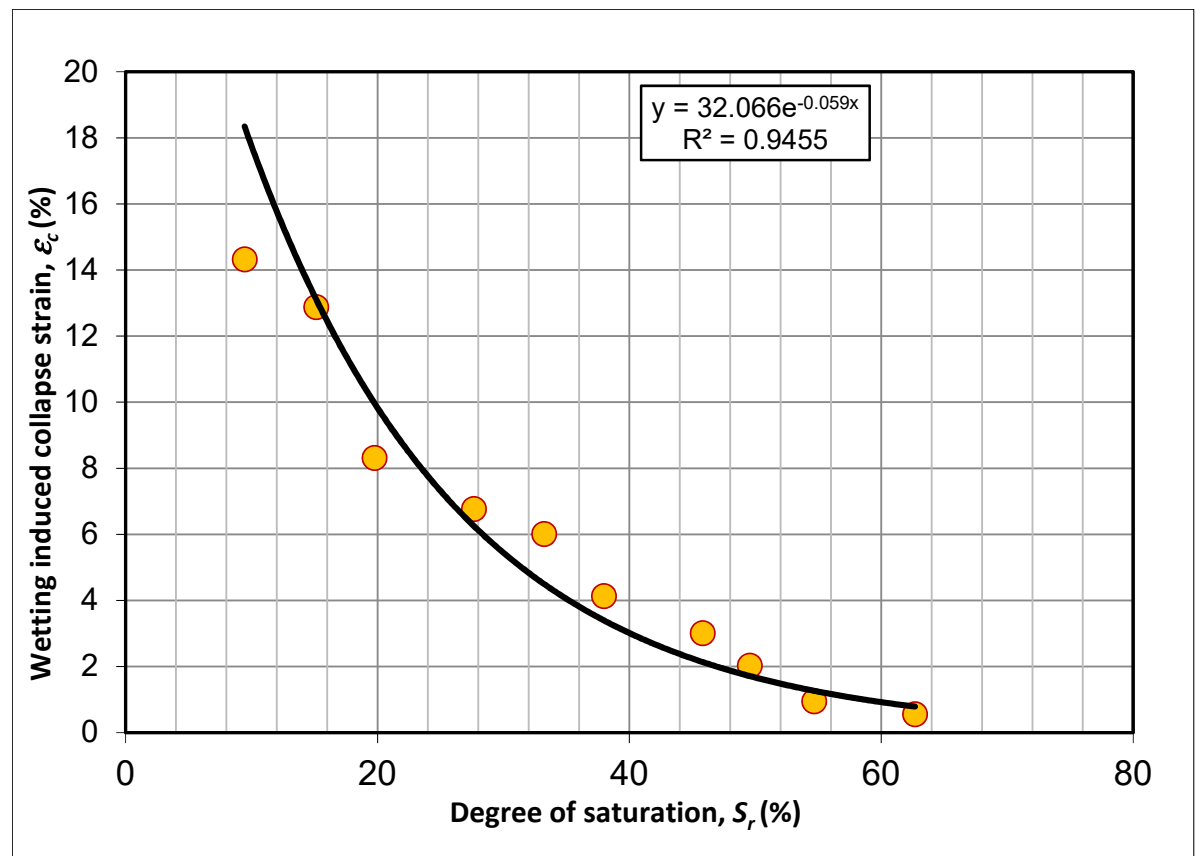

Fig. 3 Variation of wetting-induced collapse strain versus degree of saturation.

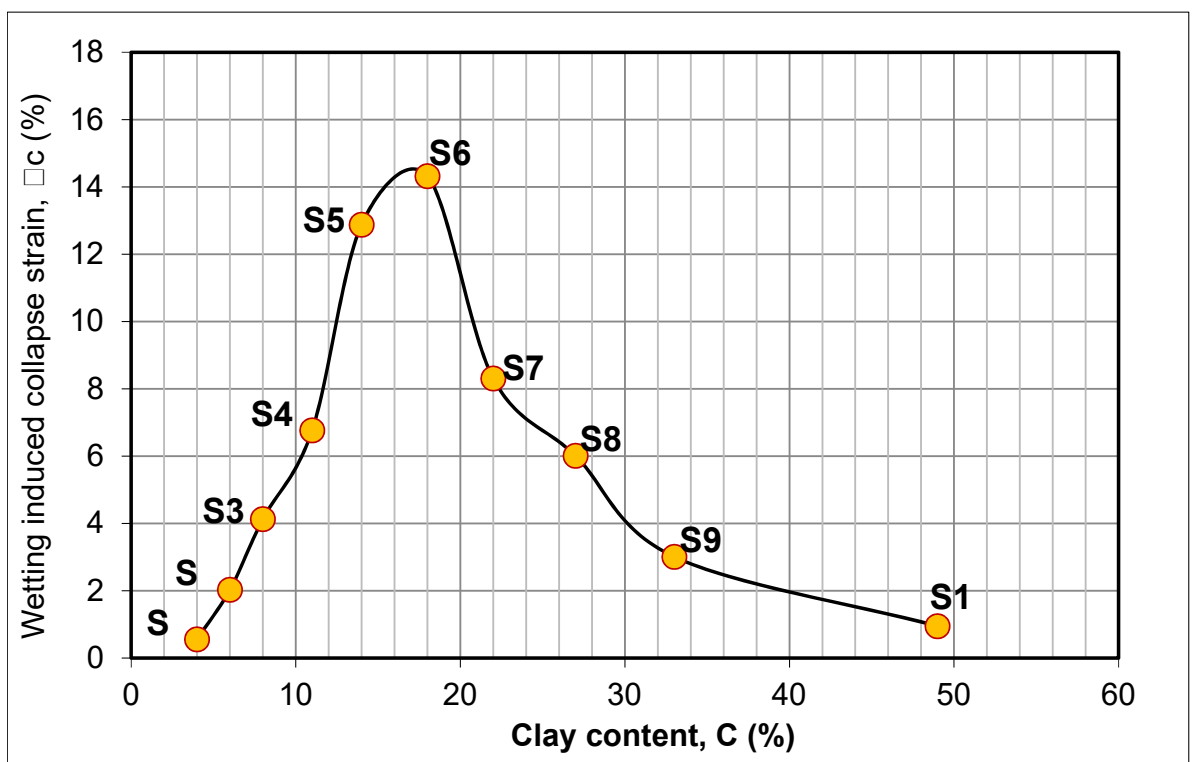

Fig. 4 Variation of wetting-induced collapse strain versus clay content.

where:

$\gamma_{d}=$ dry unit weight of soil $\left(\mathrm{kN} / \mathrm{m}^{3}\right)$,

$\mathcal{E}_{c(1)}=$ wetting-induced collapse strain related to $\gamma_{d}$ $(\%)$.

Figure 3 shows the variation of wetting-induced collapse strain with the degree of saturation. According to this figure, the collapse strain decreases with the soil's degree of saturation. It can be noted that the collapse strain is inversely proportional to the degree of saturation, and their correlation is exponential, with a coefficient of correlation $R=0.972$. This correlation can be presented by the following equation:

$\varepsilon_{c(2)} \approx 32 \times e^{-0.05 S_{r}}$ where:

$S_{r} \quad=$ degree of saturation of soil (\%),

$\mathcal{E}_{c(2)}=$ wetting-induced collapse strain related to $S_{r}$ $(\%)$.

It is worthy to note that, since the moisture content varies linearly with the degree of saturation for a given void ratio (i.e. for a given dry unit weight), it can be considered that the variation of the wetting induced collapse versus moisture content would follow the same trend as that observed for the degree of saturation.

The effect of clay content and soil grading or particle size distribution on the wetting-induced collapse strain is presented in Figures 4 and 5, respectively. In this investigation, the particle size 


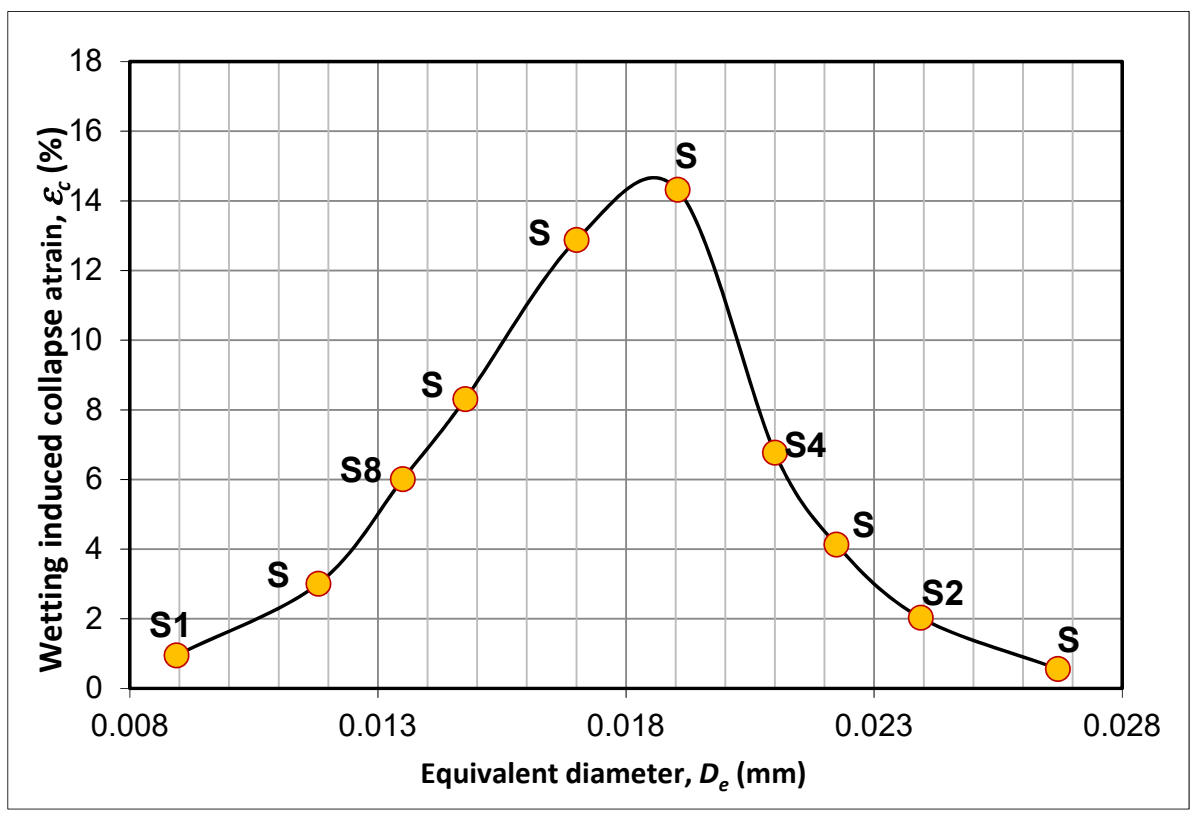

Fig. 5 Variation of wetting-induced collapse strain versus equivalent diameter.

distribution is represented by the soil equivalent diameter, $D_{e}$ (Ayadat et al., 2007c). It can be deduced from these figures that the curves representing these variations have the shape of almost symmetrical bell curves, called Gauss curves. Each curve almost has an axis of symmetry at the mean or median. Therefore, they can be approximated by the following function:

$f(x)=\frac{1}{\sigma \sqrt{2 \pi}} e^{-\frac{1}{2}\left(\frac{x-\mu}{\sigma}\right)^{2}}$

where:

$\mu \quad=$ the curve is centered on the mean,

$\sigma=$ the difference of the abscissa between the top of the curve and the point of inflection.

Based on the curves shown in Figures 4 and 5, the relationship between wetting-induced collapse and the clay content or the equivalent diameter can be presented, respectively, by the following equations:

$\varepsilon_{c(3)}=\frac{1}{15} e^{-\frac{1}{2}\left(\frac{C-17}{6}\right)^{2}}$

$\varepsilon_{c(4)}=13.3 \times e^{-\frac{1}{2}\left(\frac{D_{e}-0.0186}{0.003}\right)^{2}}$

where:

$C=$ clay content of soil $(\%)$,

$D_{e} \quad=$ equivalent diameter $(\mathrm{mm})$,

$\mathcal{E}_{c(3)}=$ wetting-induced collapse strain related to $C$ $(\%)$

$\mathcal{E}_{c(4)}=$ wetting-induced collapse strain related to $D_{e}$ $(\%)$.

The effect of the mineralogical compositions of the different tested soils on the wetting-induced collapse strain was evaluated through the main chemical components, $\mathrm{CaO}$ and $\mathrm{Al}_{2} \mathrm{O}_{3}$ (Figures 6 and 7). From these figures, it can be noted that the variations of collapse strain with $\mathrm{CaO}$ and $\mathrm{Al}_{2} \mathrm{O}_{3}$ contents follow similar trends as those observed for clay content and equivalent diameter. The maximum values of $\varepsilon_{c}$ were obtained for $53.5 \% \mathrm{CaO}$ and $8.7 \%$ $\mathrm{Al}_{2} \mathrm{O}_{3}$. The correlations between $\mathrm{CaO}$ and $\mathrm{Al}_{2} \mathrm{O}_{3}$ and wetting-induced collapse strain can be approximated by the following equations:

$\varepsilon_{c(5)}=\frac{1}{7.52} \times e^{-\frac{1}{2}\left(\frac{C a O-53.5}{3}\right)^{2}}$
$\varepsilon_{c(6)}=\frac{1}{3} \times e^{-\frac{1}{2}\left(\frac{A l_{2} O_{3}-8.7}{1.2}\right)^{2}}$

where:

$\mathrm{CaO}=\mathrm{CaO}$ content of soil $(\%)$, $\mathrm{Al}_{2} \mathrm{O}_{3}=\mathrm{Al}_{2} \mathrm{O}_{3}$ content of soil $(\%)$,

$\mathcal{E}_{c(5)}=$ wetting-induced collapse strain related to $\mathrm{CaO}$ $(\%)$,

$\mathcal{E}_{c(6)}=$ wetting-induced collapse strain related to $\mathrm{Al}_{2} \mathrm{O}_{3}$ $(\%)$.

Figure 8 shows the variation of void ratio versus load at different wetting-up stresses for soil S6. It can be noted from this figure that, due to inundation at a given applied stress, the consolidation curve of the soil passed from the curve of the unsaturated state (i.e., at initial moisture content) to the curve of the saturated state. It can be concluded that the wetting-induced collapse strain of a soil under any applied stress can be taken as the difference between the consolidation strains of the soil in the saturated and unsaturated states. Figure 9 represents the variation of the wetting-induced collapse strain versus the wetting-up stresses for soils S2, S4, S6, and S7. It was found that for an applied stress in the range tested (i.e., $50 \mathrm{kPa} \leq \mathrm{P} \leq 400 \mathrm{kPa}$ ), the collapse strain varies linearly with the applied stress. This finding is an agreement with Lutenegger and Saber (1988), Adnan 


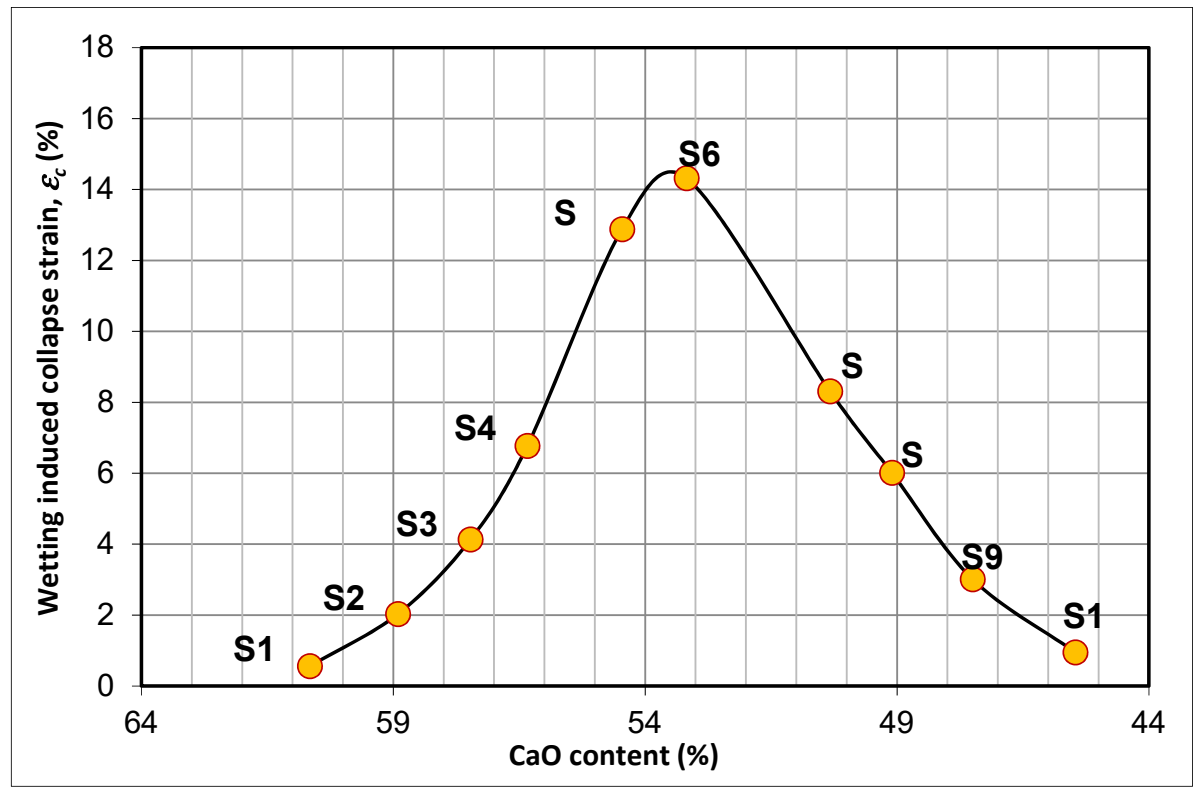

Fig. 6 Variation of wetting-induced collapse strain versus $\mathrm{CaO}$ content.

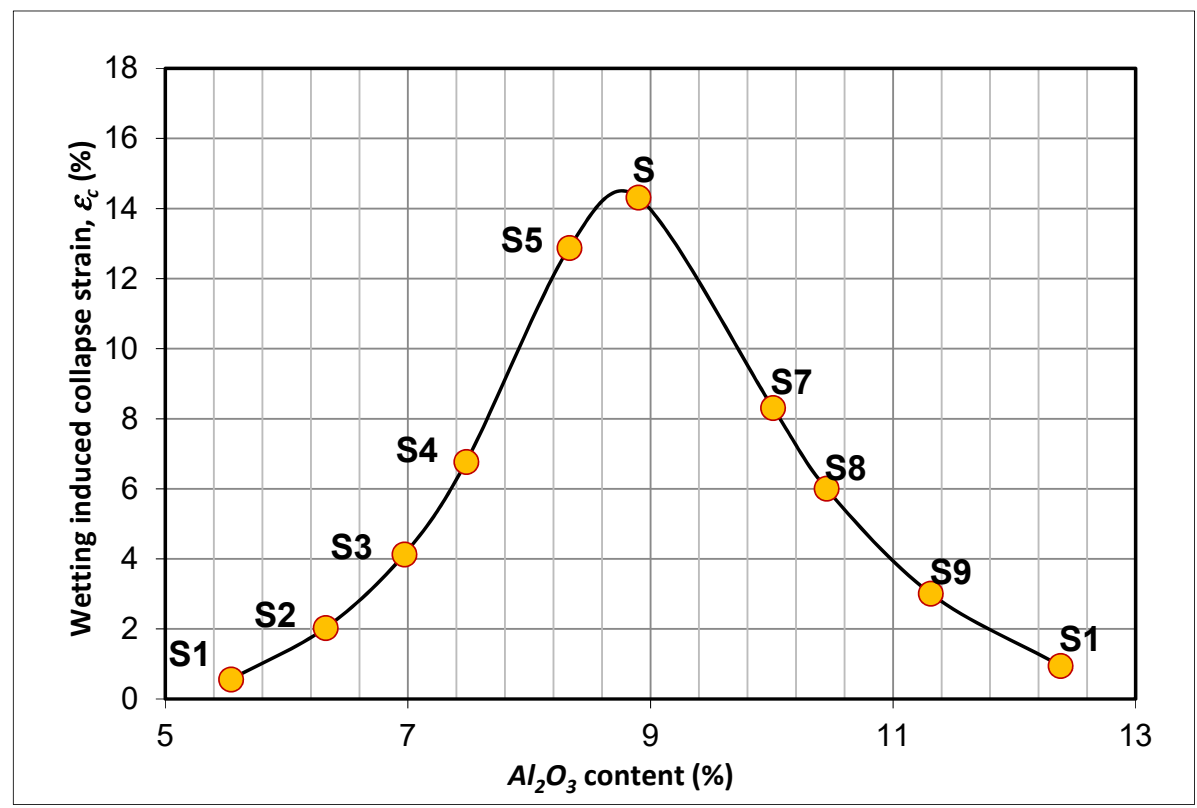

Fig. 7 Variation of wetting-induced collapse strain versus $\mathrm{Al}_{2} \mathrm{O}_{3}$ content.

and Erdil (1992), and Ayadat et al. (2007c). The wetting-induced collapse strain can be correlated to the wetting-up stress by the following relationship:

$\varepsilon_{c(7)}=0.005 \times \sigma+b$

where:

$\sigma \quad=$ inundating stress $(\mathrm{kPa})$,

$b=$ coefficient, which depends on the soil type (it was found that $\left.b=-1179 \times D_{e}+28.85\right)$,

$D_{e} \quad=$ equivalent diameter of soil (mm),

$\mathcal{E}_{c(7)}=$ wetting-induced collapse strain related to $\sigma$ (\%).

According to the classification adopted for collapsible soils, soils are considered not susceptible to collapse if $\varepsilon_{c}$ is less than 1 (ASTM D-5333, 2003). Based on the results presented in Figures 2-7, it can be advanced that the critical dry unit weight $\left(\gamma_{d}\right)$ and degree of saturation $\left(S_{r}\right)$ above which no collapse occurs are $\gamma_{d}>17.2 \mathrm{kN} / \mathrm{m}^{3}$ and $S_{r}>55 \%$. Also, the maximum values of wetting-induced collapse strain of soils is reached when the clay content $C=17 \%$, equivalent $D_{e}=0.0186 \mathrm{~mm}$, or the percentage of $\mathrm{CaO}$ is $53.5 \%$ and $\mathrm{Al}_{2} \mathrm{O}_{3}$ is $8.7 \%$. Furthermore, the wetting-induced collapse strain of soils can be estimated by the following expression:

$\varepsilon_{c}=\frac{1}{n} \sum_{i=1}^{n} \varepsilon_{c(i)}$ 


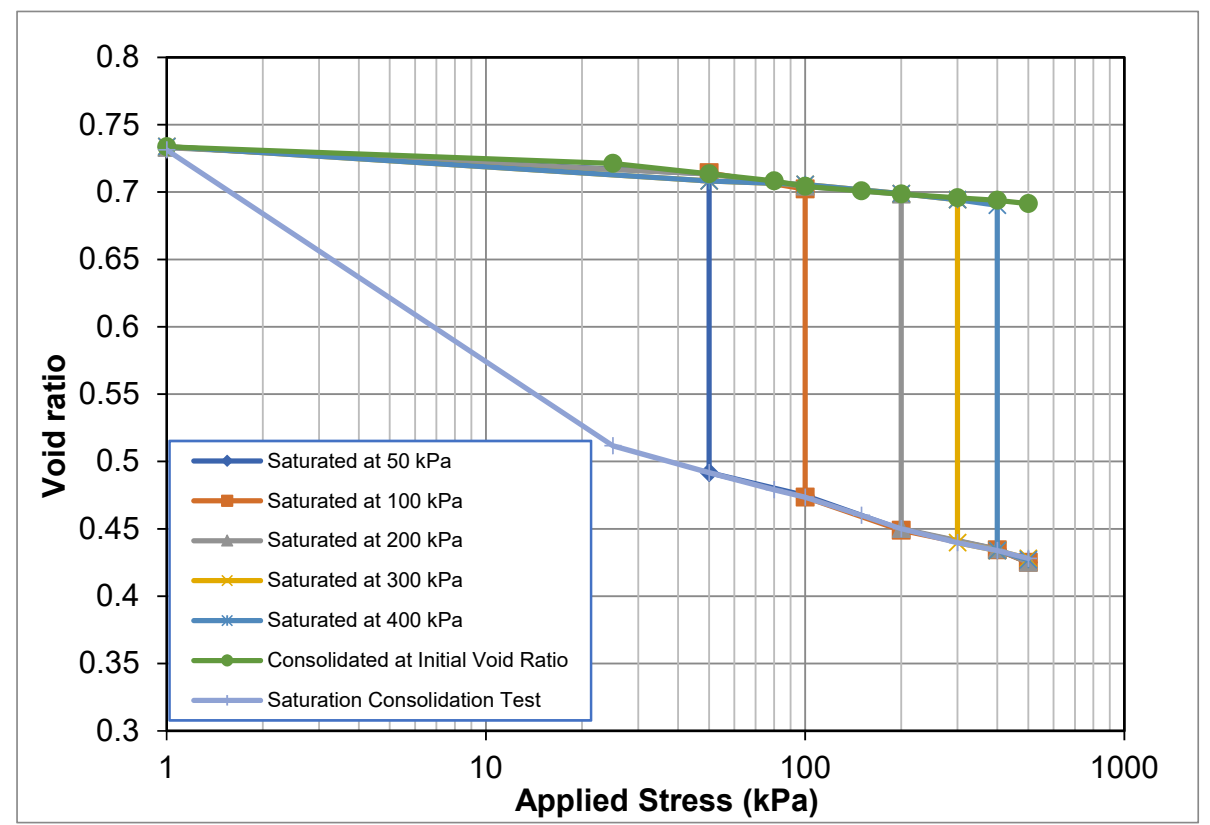

Fig. 8 Variation of void ratio versus applied stress for soil S6.

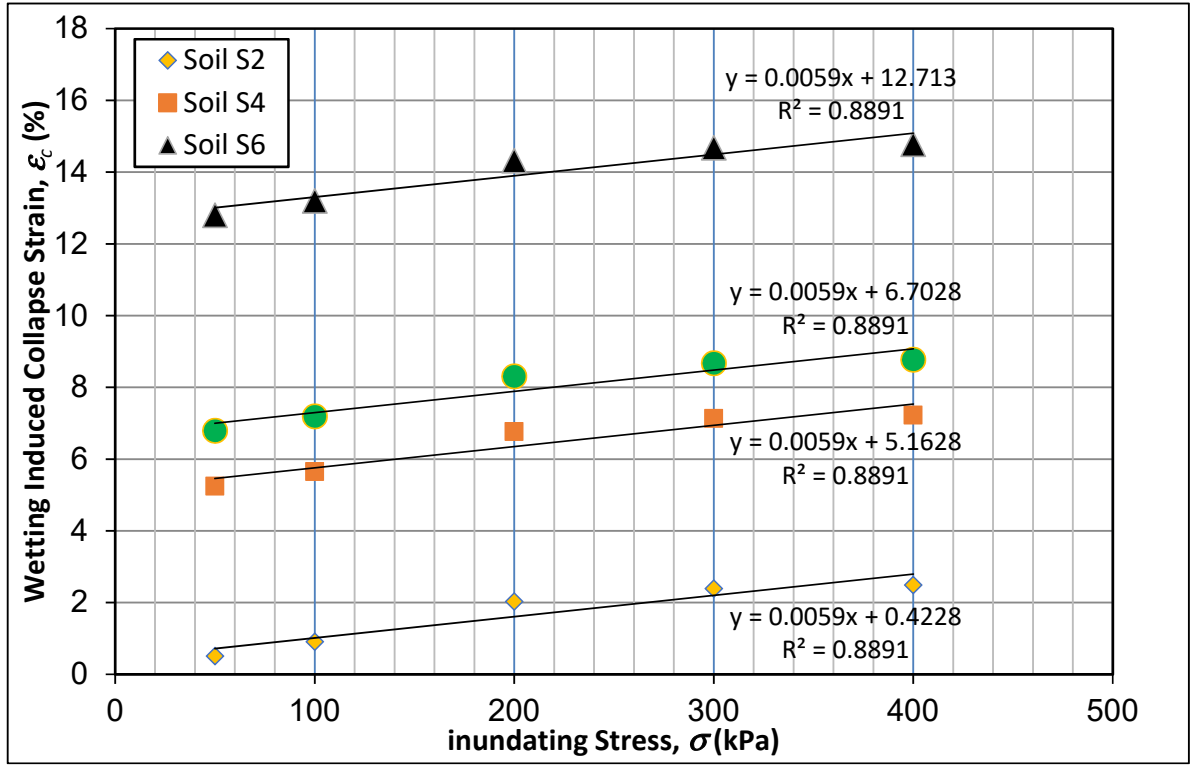

Fig. 9 Variation of collapse strain versus inundating stress for soils S2, S4, S6, and S7.

where:

$n \quad=$ number of soil parameters (e.g., $n=7$ in case all soil parameters examined in the present investigation are considered),

$\varepsilon_{c}=$ wetting-induced collapse strain of the evaluated soil (\%).

The parameters considered in this investigation for expansive soils are dry unit weight, moisture content, plasticity index, liquidity index, shrinkage index, clay content, and the ratio between effective stress and atmospheric pressure. The effective stress represents the effective overburden stress at the sampling depth of the specimens $\left(\sigma=\gamma^{\prime} z\right)$. The influence of the dry unit weight and moisture content on the wetting-induced free swelling is shown in Figures 10 and 11 , respectively. It is clear from
Figure 10 that wetting-induced free swelling increases when the dry unit weight increases. This can be explained by the fact that overconsolidated clays are more prone to swelling than normally consolidated clays. As reported by Figure 11, wetting-induced free swelling decreases as moisture increases. The variation of wetting-induced free swelling with the dry unit weight and the moisture content can be presented by the following expressions, respectively:

$\varepsilon_{s(1)}=0.012 \times e^{0.378 \gamma_{d}}$

$\varepsilon_{S(2)}=60.85 \times e^{-0.188 w_{0}}$

where:

$\gamma_{d}=$ dry unit weight $\left(\mathrm{kN} / \mathrm{m}^{3}\right)$, 


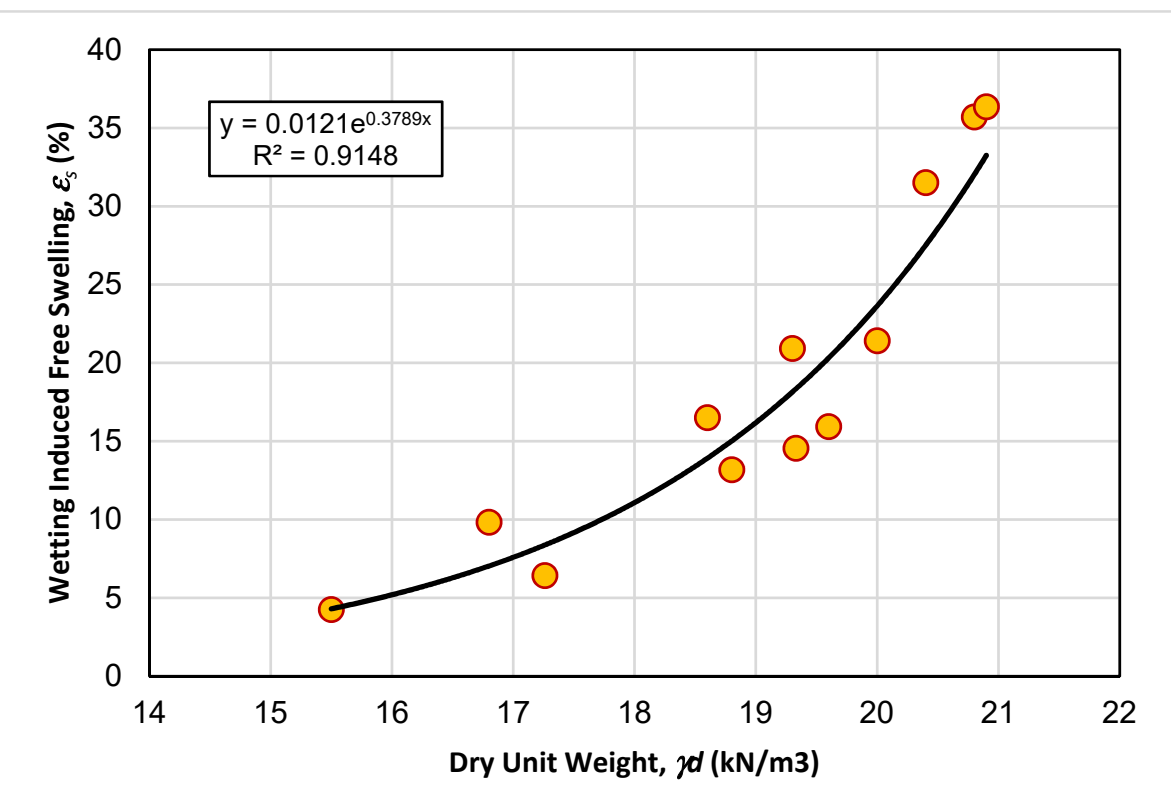

Fig. 10 Variation of wetting-induced free swelling versus dry unit weight.

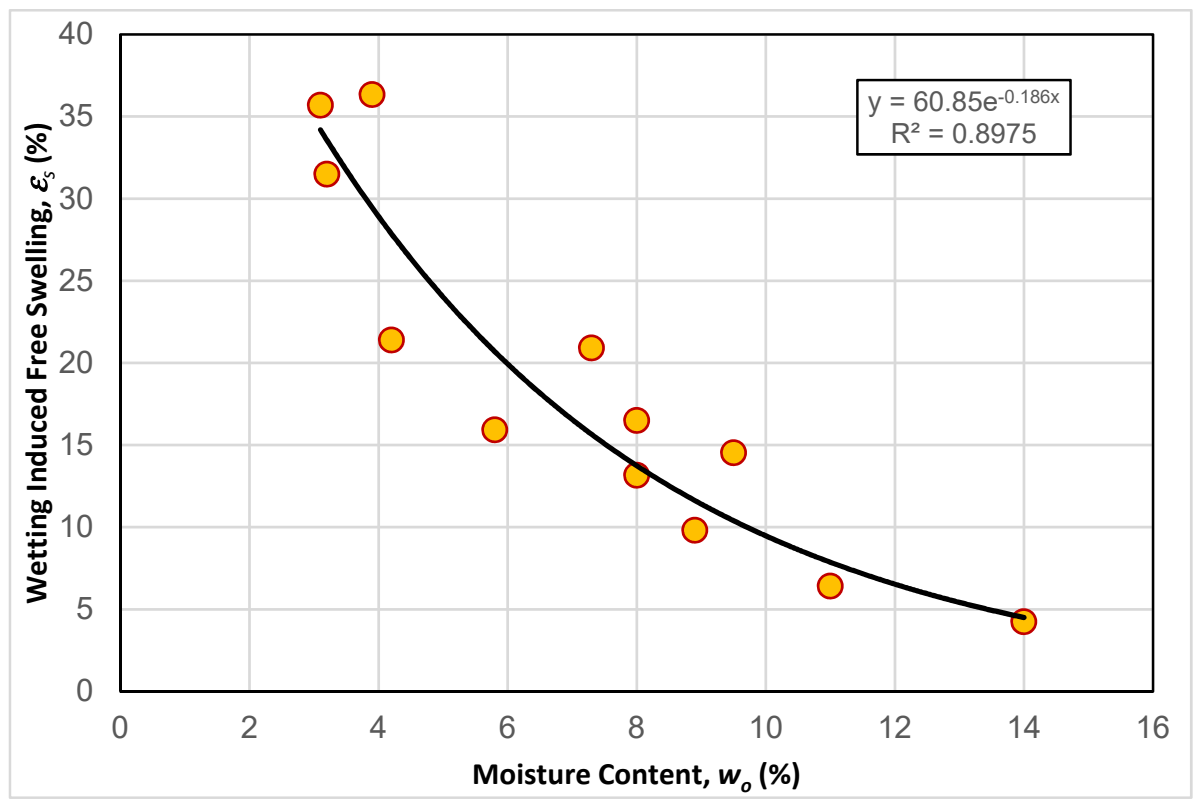

Fig. 11 Variation of wetting-induced free swelling versus moisture content.

$w_{0}=$ moisture content $(\%)$,

$\mathcal{E}_{s(1)}=$ wetting-induced free swelling related to $\gamma_{d}(\%)$,

$\varepsilon_{s(2)}=$ wetting-induced free swelling related to $w_{0}$ $(\%)$.

The variation of wetting-induced free swelling versus the plasticity index, liquidity index, and shrinkage index is illustrated respectively in Figures 12, 13, and 14. The shrinkage index is defined as the difference between the liquidity and shrinkage limits $(I R=L L-S L)$. It can be deduced from these figures that wetting-induced free swelling increases along with the plasticity index, whereas it decreases when the liquidity index or shrinkage index increases. However, the relationship or the correlation between any of these three parameters and wetting-induced free swelling adheres to an exponential function with a coefficient of correlation ranging between $R=0.912$ and 0.928 . The different correlations can be presented by the following equations:

$$
\begin{gathered}
\varepsilon_{S(3)}=0.303 \times e^{0.082 I P} \\
\varepsilon_{S(4)}=3.175 \times e^{-5.0 I L} \\
\varepsilon_{S(5)}=1775 \times e^{-0.08 I R}
\end{gathered}
$$

where:

IP = plasticity index,

$I L \quad=$ liquidity index,

$I R$ = shrinkage limit,

$\mathcal{E}_{s(3)}=$ wetting-induced free swelling related to $I P$ $(\%)$ 


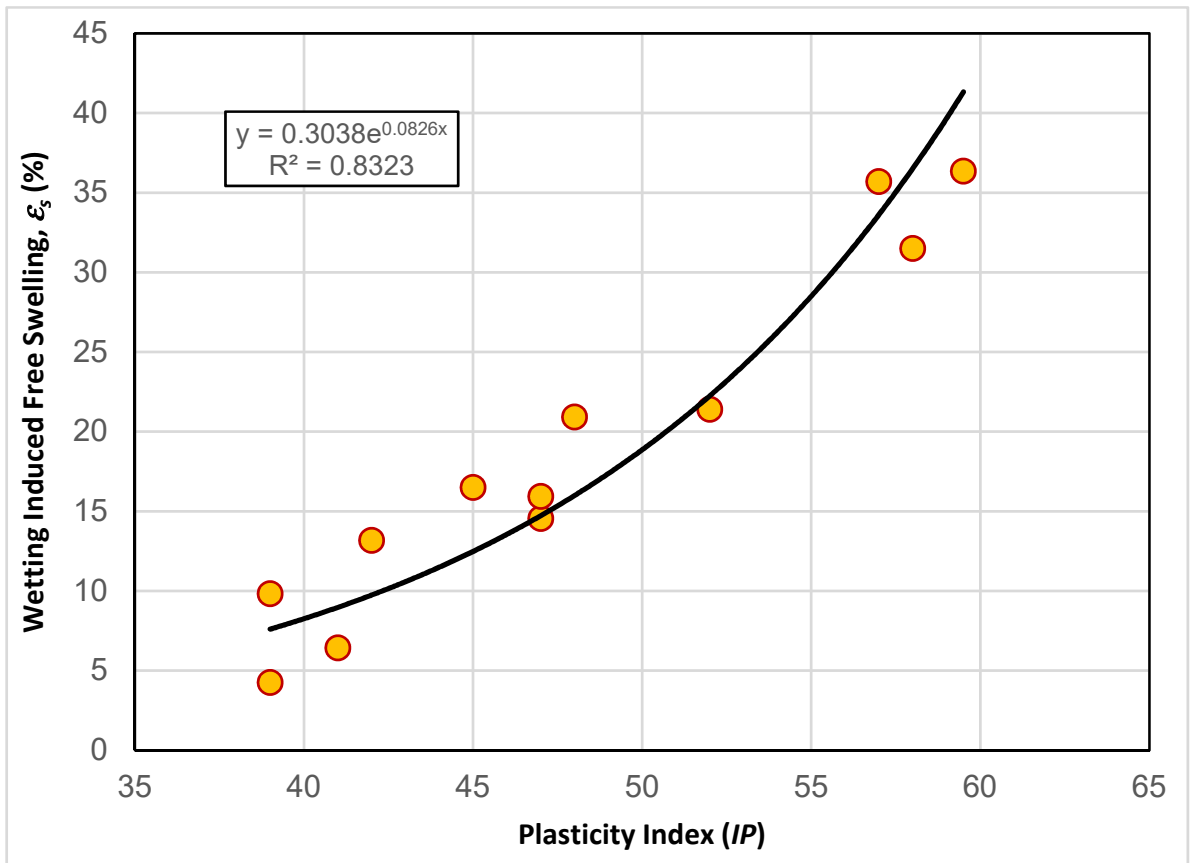

Fig. 12 Variation of wetting-induced free swelling versus plasticity index.

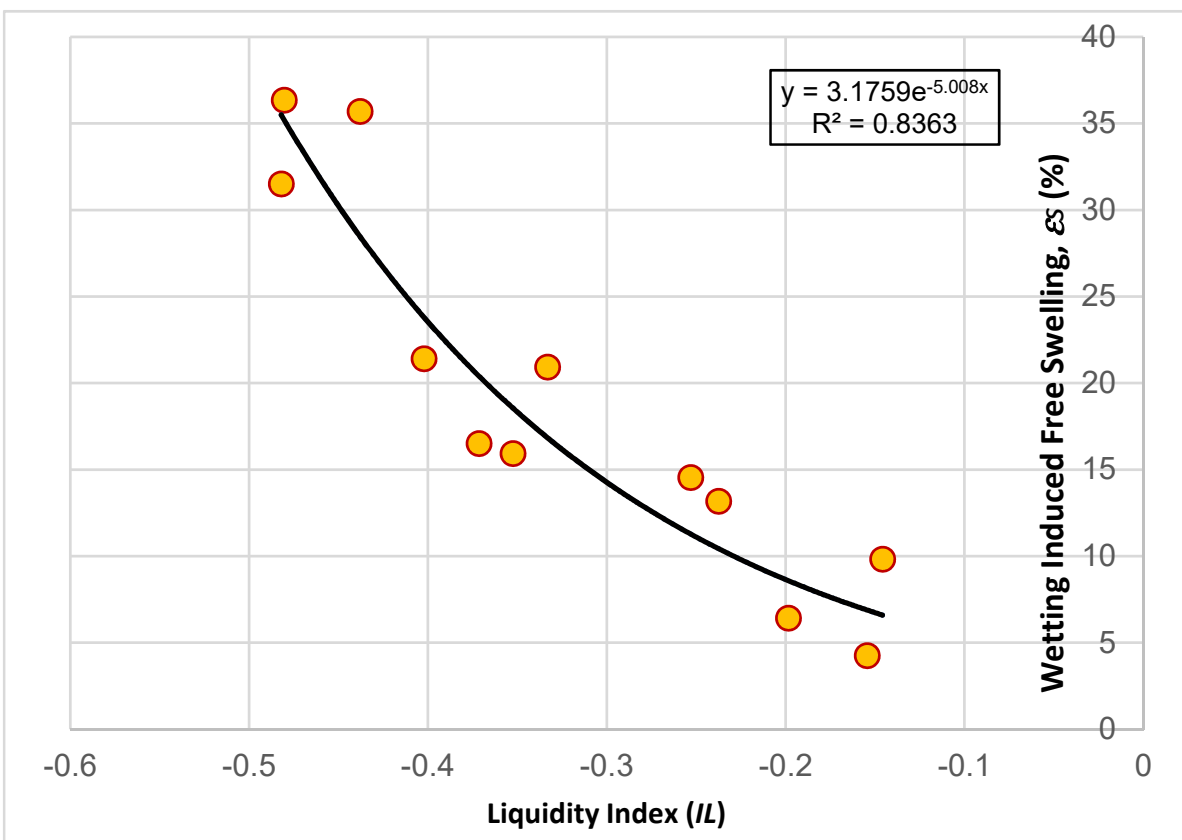

Fig. 13 Variation of wetting-induced free swelling versus liquidity index.

$\mathcal{E}_{S(4)}=$ wetting-induced free swelling related to $I L$ $(\%)$

$\mathcal{E}_{s(5)}=$ wetting-induced free swelling related to $I R$ $(\%)$.

Figure 15 shows the variation of the clay content on the wetting-induced free swelling. As noted from this figure, increasing the clay content leads to an increase on the wetting-induced free swelling. This observation concords well with the findings of Nayak and Christensen (1971) and Vijayvergiya and Gazzhaly (1973). The wetting-induced free swelling can be correlated by the following relationship: $\varepsilon_{s(6)}=1.182 \times e^{0.045 C}$

where:

$C=$ clay content

$\mathcal{E}_{S(6)}=$ wetting-induced free swelling related to $C(\%)$

The influence of the ratio $\frac{\sigma^{\prime}}{P_{a}}$ on the wettinginduced free swelling is presented in Figure 16. The free swelling increases when this ratio increases. This can be explained by the fact that clays located at deeper depth are subjected to large overburden stresses and are more confined, so they are more overconsolidated than clays at shallow depth. The 


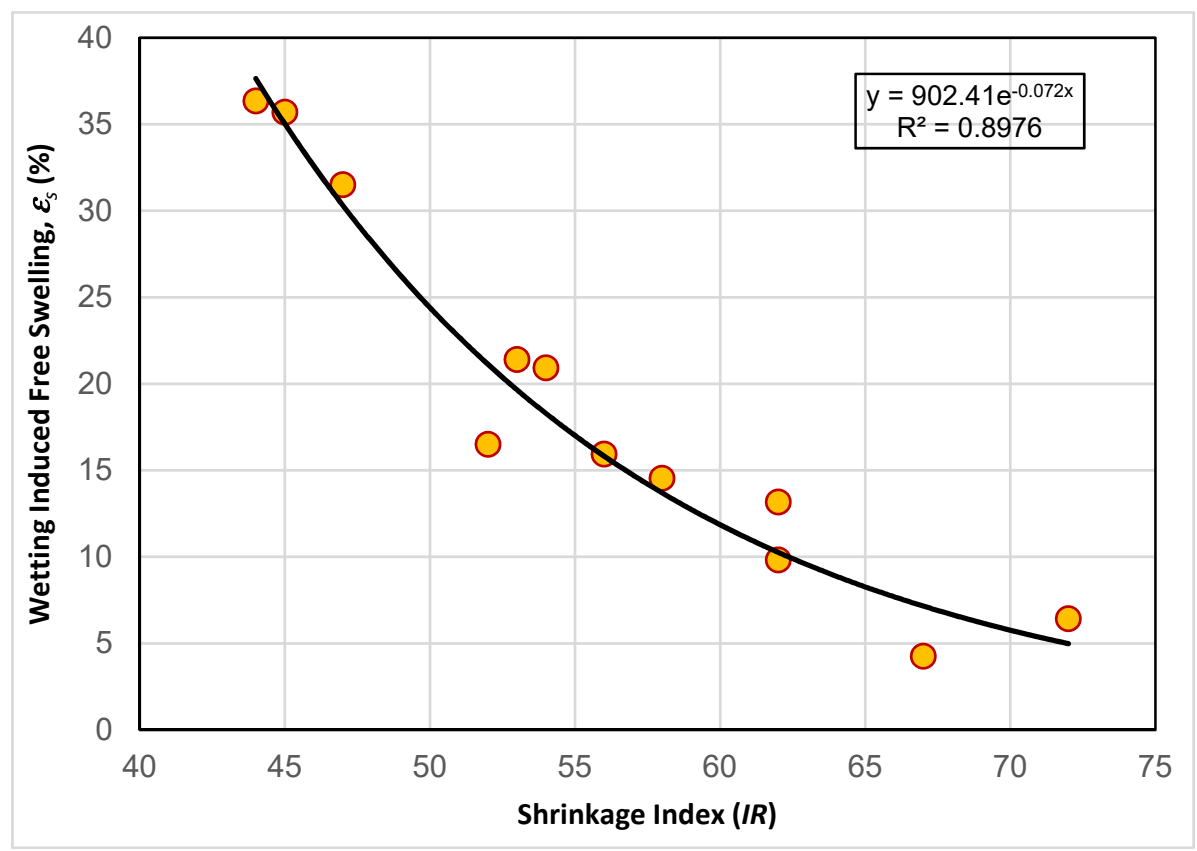

Fig. 14 Variation of wetting-induced free swelling versus shrinkage index.

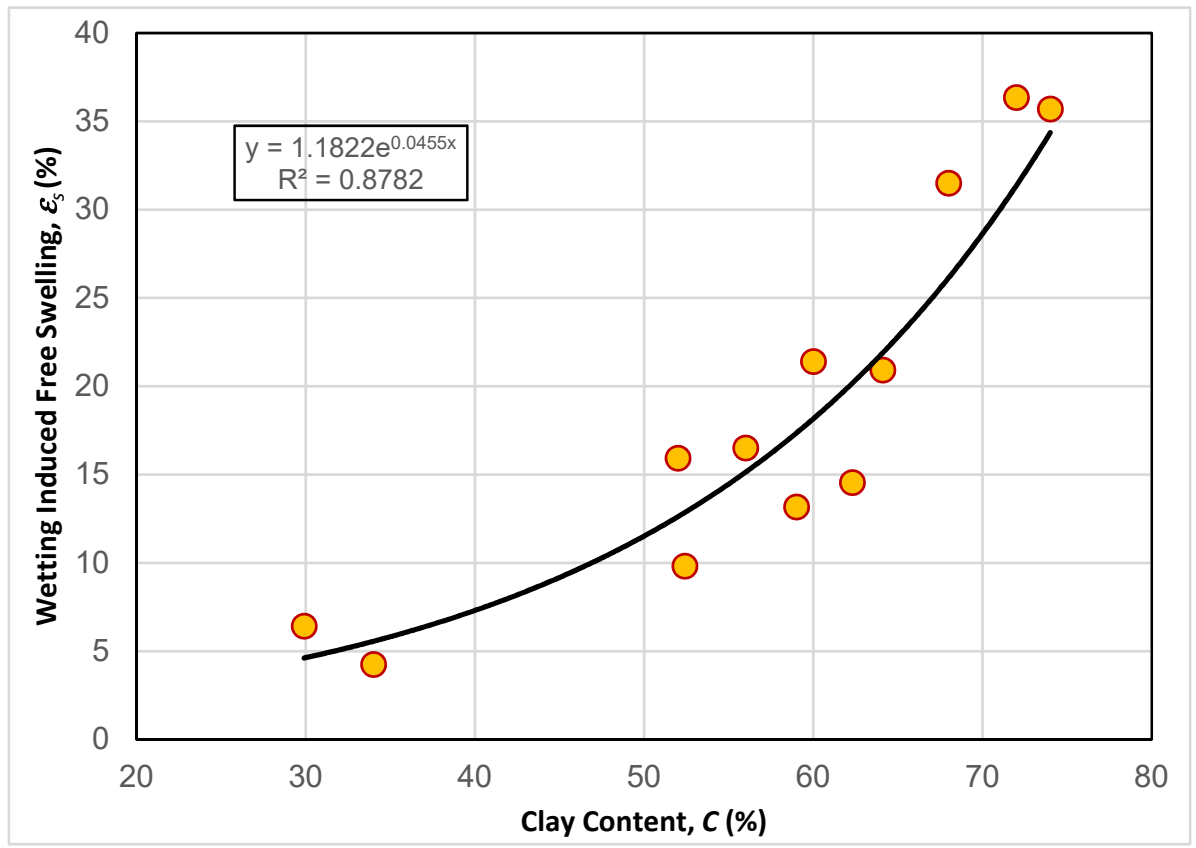

Fig. 15 Variation of wetting-induced free swelling versus clay index.

variation noted in Figure 16 can be represented by the following equation:

$\varepsilon_{s(7)}=2.671 \times e^{5.81 \frac{\sigma^{\prime}}{P_{a}}}$

where:

$\frac{\sigma^{\prime}}{P_{a}}=$ ratio $\left(\sigma^{\prime}\right.$ is the effective stress applied on specimen at sampling depth, and $P_{a}$ is the atmospheric pressure),

$\varepsilon_{s(7)}=$ wetting-induced free swelling related to $\frac{\sigma^{\prime}}{P_{a}}(\%)$.

It can be concluded that the wetting-induced free swelling of soils can be estimated by the following expression: $\varepsilon_{s}=\frac{1}{n} \sum_{i=1}^{n} \varepsilon_{s(i)}$

where:

$n \quad=$ number of soil parameters (e.g., $n=7$ in case all soil parameters examined in the present investigation are considered),

$\mathcal{E}_{s} \quad=$ wetting-induced free swelling of the evaluated soil $(\%)$.

For the case of liquefiable soils, as mentioned based on many liquefaction cases observed in the field and in laboratory works, and according to the results of a large number of verifications performed on different soils to evaluate their liquefaction 


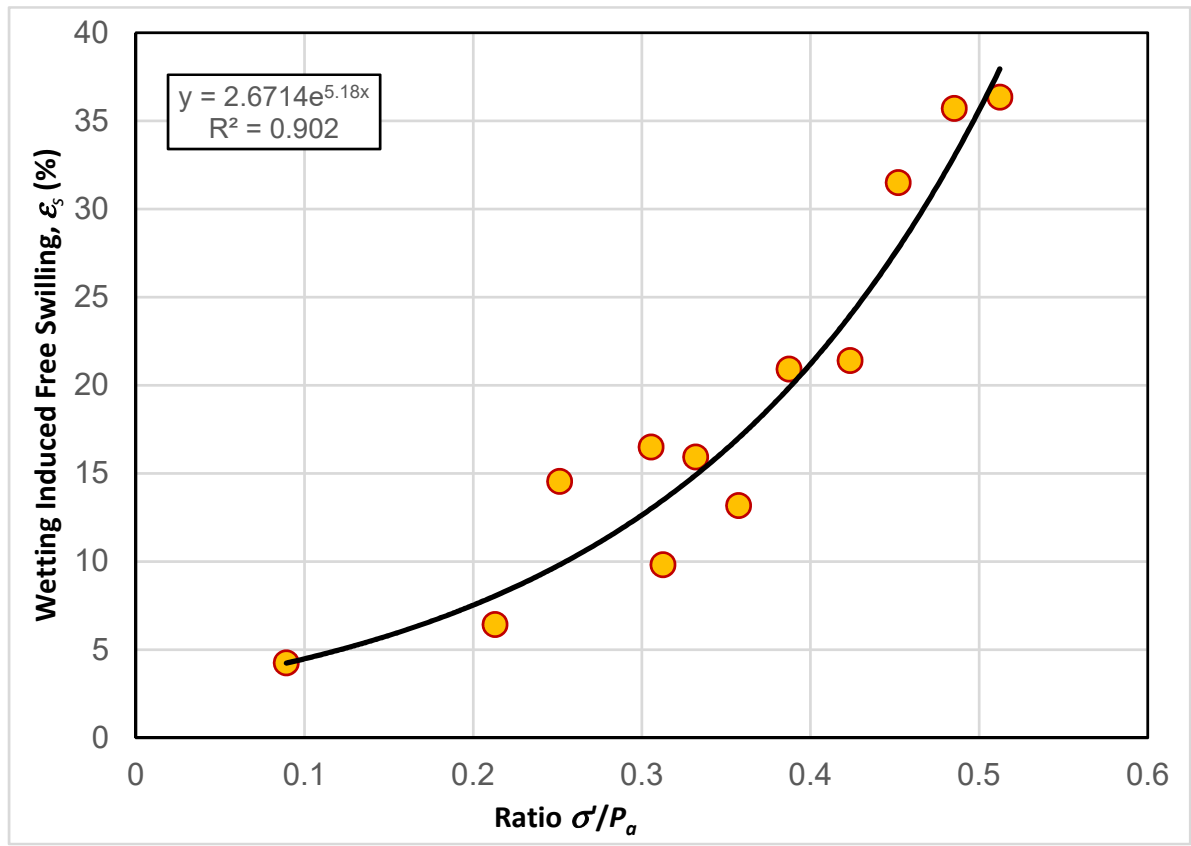

Fig. 16 Variation of wetting-induced free swelling versus versus the ratio $\sigma^{\prime} / P_{a}$.

susceptibility using the two methods described previously, namely the methods of Prakash (1981) and the NCEER working group (NCEER, 1997), a new procedure or evaluation guide was developed for the purpose of liquefaction assessment based on a rapidly performed index. It was realized from these observations and evaluations that the different conditions suggested to assess the susceptibility of a given soil to liquefaction can be grouped into five different conditions, summarized as follows:

\section{Condition 1:}

The site of the projected construction should be located in an active seismic zone, where the maximum acceleration at the ground surface (peak ground acceleration, PGA) has to be greater than 0.13 .

\section{Condition 2:}

The evaluated soil deposit must be granular and submerged or situated below the water table (i.e., mostly or fully saturated, where its degree of saturation $S_{r} \geq 95 \%$ ).

\section{Condition 3:}

Furthermore, the particle size distribution of the soil has to be checked against the curves shown in Figure A2 (Appendix A). The grading curve of the tested soil should lies within the suggested boundaries of this figure. By considering diameters $D_{15}, D_{50}$ and $D_{85}$, these boundaries can be summarized as follows:

- Liquefiable soil: $0.05 \leq D_{15} \leq 0.44$ and $0.08 \leq D_{50} \leq 0.70$ and $0.14 \leq D_{85} \leq 1.2$

- Potentially liquefiable: $0.014 \leq D_{15} \leq 0.05$ and $0.02 \leq D_{50} \leq 0.08$ and $0.032 \leq D_{85} \leq 0.14$

Or $0.44 \leq D_{15} \leq 1.4$ and $0.70 \leq D_{50} \leq 1.9$ and $1.2 \leq D_{85} \leq 3.5$

\section{Condition 4:}

The soil has to be in a loose to medium-dense state (i.e., on the standard penetration test index, $N \leq 20)$. This value of $N$ corresponds to a soil unit weight on the order of $17.5 \mathrm{kN} / \mathrm{m}^{3}$ (Bowles, 1997). However, susceptibility to liquefaction for soil having between 20 and 30 blows $/ 30 \mathrm{~cm}$ has also been observed, and liquefaction in such case should not be ruled out.

\section{Condition 5:}

If the soil deposit is not located at the ground surface, verification should be carried out as per Figure A3 (Appendix A). According to this figure, a granular soil deposit is considered as susceptible to liquefaction if its thickness fulfills one of the following relationships:

- when $a=0.2: \quad H_{2} \geq H_{1} \quad$ and $\quad H_{1} \leq 3.0 \mathrm{~m}$

- when $a=0.3: \quad H_{2} \geq 0.67 H_{1}$ and $H_{1} \leq 6.0 \mathrm{~m}$

- when $a=0.4$ to 0.5 : $H_{2} \geq 0.47 H_{1}$ and $H_{1} \leq 8.5 \mathrm{~m}$

For simplicity and convenience, these five conditions were grouped and presented in a table as an evaluation guide (Table 2). It is worthwhile to note that (Table 2):

- $\quad$ For items 1, 2, 3.1, 4.1, 5.1, 5.2, and 5.3, if the condition is fulfilled, a value of 1 is assigned in column 4 , whereas 0 is assigned if the condition is not fulfilled.

- For items 3.2 and 4.2, if the condition is fulfilled, a value of 0.5 is assigned in column 4 . This is because the soil is only potentially liquefiable (i.e., the probability is $50 \%$ ). 
Table 2 Evaluation guide for soil liquefaction assessment.

\begin{tabular}{|c|c|c|c|c|}
\hline \multirow[t]{2}{*}{ Conditions } & \multirow[t]{2}{*}{ Item } & \multicolumn{3}{|l|}{ Evaluation } \\
\hline & & Condition to be Checked & $\begin{array}{l}\text { Fulfilled or Not } \\
\text { Fulfilled* }\end{array}$ & $\begin{array}{l}\text { Potential of } \\
\text { Liquefaction }\end{array}$ \\
\hline Condition \#1 & 1 & $a \geq 0.13$ & & \multirow{5}{*}{ 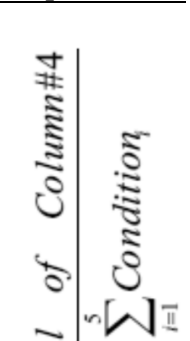 } \\
\hline Condition \#2 & 2 & Saturated $(S \geq 95 \%)$ & & \\
\hline \multirow[t]{3}{*}{ Condition \#3 } & 3.1 & $\begin{array}{l}0.05 \leq \mathrm{D} 15 \leq 0.44 \text { and } 0.08 \leq \mathrm{D} 50 \leq 0.70 \text { and } \\
0.14 \leq \mathrm{D} 85 \leq 1.2\end{array}$ & & \\
\hline & & $\begin{array}{l}0.014 \leq \mathrm{D} 15 \leq 0.05 \text { and } 0.02 \leq \mathrm{D} 50 \leq 0.08 \text { and } \\
0.032 \leq \mathrm{D} 85 \leq 0.14\end{array}$ & & \\
\hline & 3.2 & $\begin{array}{l}0.44 \leq \mathrm{D} 15 \leq 1.4 \text { and } 0.70 \leq \mathrm{D} 50 \leq 1.9 \text { and } \\
1.2 \leq \mathrm{D} 85 \leq 3.5\end{array}$ & & \\
\hline \multirow[b]{2}{*}{ Condition \#4 } & 4.1 & $0 \leq \mathrm{N} \leq 20$ & & \multirow{2}{*}{$\frac{9}{3}$} \\
\hline & 4.2 & $20<\mathrm{N} \leq 30$ & & \\
\hline \multirow{3}{*}{ Condition \#5 } & 5.1 & $H_{2} \geq H_{1}$ and $H_{1} \leq 3.0 \mathrm{~m}($ for $a=0.2)$ & & \multirow{3}{*}{$\stackrel{2}{\prime \prime}$} \\
\hline & 5.2 & $H_{2} \geq 0.67 H_{1}$ and $H_{1} \leq 6.0 \mathrm{~m}($ for $a=0.3)$ & & \\
\hline & 5.3 & $H_{2} \geq 0.47 H_{1}$ and $H_{1} \leq 8.5 \mathrm{~m}($ for $a=0.4-0.5)$ & & \\
\hline & & & Total $=\Sigma$ & \\
\hline
\end{tabular}

Table 3 Validation of Equation (14) developed for estimating wetting-induced collapse strain.

\begin{tabular}{cllllllrrr}
\hline Reference & $\begin{array}{c}D_{e} \\
(\mathrm{~mm})\end{array}$ & $\begin{array}{c}\gamma_{d} \\
\left(\mathrm{kN} / \mathrm{m}^{3}\right)\end{array}$ & $\begin{array}{c}C \\
(\%)\end{array}$ & $\begin{array}{c}S_{r} \\
(\%)\end{array}$ & $\begin{array}{c}\sigma \\
(\mathrm{kPa})\end{array}$ & $\begin{array}{c}\mathrm{CaO} \\
(\%)\end{array}$ & $\begin{array}{c}\mathrm{Al}_{2} \mathrm{O}_{3} \\
(\%)\end{array}$ & \multicolumn{2}{c}{$\mathcal{E}_{c}(\%)$} \\
\cline { 5 - 10 } Present & 0.01904 & 15 & 18 & 9.5 & 200 & 53.18 & 8.9 & 14.86 & 14.32 \\
Investigation & 0.0135 & 16.04 & 27 & 33.22 & 200 & 49.1 & 10.45 & 6.51 & 6.01 \\
& 0.02394 & 17 & 6 & 49.55 & 200 & 58.91 & 6.32 & 2.38 & 2.03 \\
\hline Ayadat et al. & 0.0213 & 15.15 & 15.4 & 7.34 & 200 & 58.31 & 10.35 & 11.23 & 10.04 \\
$(2007)$ & 0.0154 & 16.33 & 19.5 & 18.84 & 200 & 61.68 & 12.52 & 4.31 & 3.63 \\
& 0.0227 & 17.27 & 8.3 & 22.09 & 200 & 63.78 & 7.88 & 2.26 & 1.38 \\
\hline Bigdeli & 0.0146 & 13.0 & 22 & 4 & 100 & - & - & 9.21 & 8.50 \\
$(2018)$ & 0.0146 & 13.75 & 22 & 3 & 100 & - & - & 6.15 & 5.40 \\
\hline Boudaghpour & 0.0183 & 14.1 & 18 & 2.26 & 200 & - & - & 11.34 & 10.65 \\
$(2016)$ & 0.0149 & 15 & 11 & 2.6 & 200 & - & - & 5.41 & 4.87 \\
\hline
\end{tabular}

Table 4 Validation of Eauation (14) develoned for estimating wetting-induced collanse strain.

\begin{tabular}{cccccccccc}
\hline Reference & $\gamma_{d}\left(\mathrm{kN} / \mathrm{m}^{3}\right)$ & $w_{o}(\%)$ & $I P$ & $I R$ & $I L$ & $\mathrm{C}(\%)$ & $\sigma^{\prime} / P_{a}$ & \multicolumn{2}{c}{$\mathcal{E}_{S}(\%)$} \\
\cline { 7 - 10 } & & & & & & & & & \multicolumn{2}{c}{ Equation $(22)$} & Testing \\
\hline Present & 16.8 & 8.9 & 39 & 62 & -0.146 & 52.4 & 0.312 & 8.79 & 9.82 \\
Investigation & 19.3 & 7.3 & 48 & 54 & -0.333 & 64.1 & 0.378 & 19.56 & 20.92 \\
& 20.9 & 3.6 & 59.5 & 44 & -0.480 & 72 & 0.512 & 35.22 & 36.35 \\
\hline Derriche and & 17.26 & 11 & 57 & 72 & -0.280 & 29.9 & 0.212 & 4.55 & 3.92 \\
Kebaili & 20.9 & 2.6 & 23 & 30 & -0.756 & 52 & - & 14.63 & 13.43 \\
$(1998)$ & 17.06 & 7.3 & 52 & 63 & -0.282 & 65.1 & 0.387 & 19.59 & 18.42 \\
\hline Khemissa et al.. & 18.49 & 14.63 & 21.87 & 64.9 & -0.334 & 24.2 & - & 6.12 & 4.10 \\
$(2015)$ & 18.68 & 16.20 & 30.25 & 64.2 & -0.435 & 55.0 & - & 20.67 & 18.44 \\
\hline Forouzan (2016) & 13.6 & 29.4 & 14.64 & 45.58 & -2.97 & 39 & - & 9 & 6 \\
& 12.6 & 36.2 & 83.3 & 182.42 & -1.95 & 49 & - & 13.2 & 10.5 \\
\hline
\end{tabular}

- The potential for liquefaction can be calculated by the following relationship:

$P Q=\frac{\text { Total of Column\#4 }}{\sum_{i=1}^{5} \text { Condition }_{i}}$

\section{VALIDATION}

Validation of the proposed relationships or correlations is performed by comparing some experimental data reported in literature of collapse strain and free swelling and the results obtained from the predictive models (i.e., Equations 14 and 22). As can be noted from Tables 3 and 4, the predictive models proposed in this investigation are capable of estimating wetting-induced collapse strain and wetting-induced free swelling with acceptable accuracy. 
The proposed evaluation procedure for the assessment of soil liquefaction was applied to a practical case (identified in the laboratory as liquefiable ground) in order to validate and clarify the different steps to be followed during the evaluation. The case or the project selected for this purpose consisted of the construction of a new electrical station in Chatham-Kent, Ontario, Canada. A detailed description of the project, including field and laboratory works undertaken, and soil description are given in Ayadat (2017). In addition, some of the relevant information required in this investigation is summarized in this section.

Generally, the site of the project is made up of three horizons. At the ground surface, a thin sandy layer with some vegetable roots was identified in almost the entire area of the project. The thickness of the sampled layer varied between 0.20 and $0.30 \mathrm{~m}$. It was constituted generally by a matrix of brown sand mixed with some organic matter and vegetable roots in different proportions. Below the sandy topsoil, a thick deposit of fine to coarse, brown, and dry to saturated homogeneous sandy soil was encountered. The thickness of the sampled layer varied between $2.4 \mathrm{~m}$ and $5.4 \mathrm{~m}$. The value of the index of the standard penetration test in all layers was generally situated between 2 and 37, indicating that the soil was generally in a loose to medium-dense state. The results of the particle size distributions indicated that the soil was composed of 0-13\% gravel, 60-94\% sand, and about 8-26\% silt (particles less than $80 \mu \mathrm{m}$ ). Generally, the soil of this layer can be classified as sand with some silt and traces of gravel. A thick layer of brown to grey, mainly saturated silt and clay was encountered beneath the brown saturated sand. The thickness of the sampled layer varied between $0.4 \mathrm{~m}$ and $7.3 \mathrm{~m}$. The different values of the index of standard penetration test $\mathrm{N}$ are generally in the range of 12 to 28 , which indicate that the deposit is stiff to very stiff. The results obtained from the different sieve analyses and hydrometer tests indicate that the soils encountered in this layer are composed of 4-20\% sand, $42-58 \%$ silt (particles less than $80 \mu \mathrm{m}$ ), and $30-53 \%$ clay (particles less than $2 \mu \mathrm{m}$ ). The soils can be classified as silt and clay with little/traces of sand. According to the results of consistency tests carried out on samples of silt and clay, the liquid limit of these soils was in the range of $29 \%$ and $40 \%$, and the plastic limit was in the range of $15 \%$ and $19 \%$. The moisture content values were found to be lower than the liquid limit, which indicate that the silt and clay is not sensitive. Based on these results, the silt and clay soil is classified as soil of type CL2 (low plasticity). The ground water level was monitored by five piezometers installed in different boreholes. The different water levels measured in the summer varied between $1.86 \mathrm{~m}$ and $2.82 \mathrm{~m}$. Moreover, the site of the project is characterized by a maximum acceleration factor at the surface of 0.2 , corresponding to a probability of going beyond $10 \%$ in 50 years. This acceleration factor was obtained by interpolation using the interpolation tool of seismic values addressed by Natural Resources Canada.

The deposit encountered under the sandy top soil (i.e., the deposit of brown sand) is classified as granular soil (mainly composed of sand), loose to medium-dense, and mostly saturated. Consequently, verification of susceptibility to liquefaction was carried out using the evaluation procedure or guide proposed in this investigation (Table 5). The assessment grouped in this table can be summarized as follows:

- The project site is located in an active seismic zone, where the maximum acceleration at the ground surface is on the order of 0.2.

- The brown sand is granular and mostly situated below the water table, i.e., mostly in fully saturated condition.

- According to the grain size distribution of some soil samples grouped in Table 6, the particle size of the soil lies within the boundaries indicated in item 3.1 of the evaluation guide.

- The state of the soil is loose to medium-dense (the values of the index of the standard penetration test in all layers are situated generally between 2 and 37).

- The thickness condition is fulfilled. The thickness of the deposit $\left(\mathrm{H}_{2}\right)$ varied between $2.4 \mathrm{~m}$ and $5.4 \mathrm{~m}$, while the thickness of the sandy top layer $\left(H_{l}\right)$ varied between 0.20 and $0.30 \mathrm{~m}$ (i.e., $a=0.2$, $H_{2}$ is greater than $H_{1}$, and $H_{l}$ is less than $3.0 \mathrm{~m}$ ).

Therefore, conditions 1, 2, 3, and 5 are fulfilled, and consequently, a value of 1 is assigned for each of these conditions in column 4 of Table 5. However, for condition 4 , because $N$ is situated between 2 and 37 , the value of 0.5 is assigned (the probability of this condition is only $50 \%$, since the condition might or might not be fulfilled). Accordingly, and based on the results of the evaluation grouped in Table 5, the site's liquefaction potential is $P Q=90 \%$.

In order to confirm the results of this evaluation, another verification was performed using the Prakash method described previously (Equations 1 and 2). The results obtained for three arbitrary boreholes $(2,3$, and 9) are grouped in Table 7. It can be noted from this table that the values of the shearing stress due to earthquake $\left(\tau_{a v}\right)$ are greater than those of the critical shearing resistance of the soil $\left(\tau_{c r}\right)$ at any given depth, indicating that the soil is susceptible to liquefaction.

Although the developed models were validated against some data reported in literature for different type of collapsible, swelling, and liquefiable soils, it is important to mention that the findings of the present investigation are based on collapsible clayey sands, montmorillonite swelling clays, and sandy liquefiable soils. The hypotheses are tested, results obtained, and conclusions drawn for these specific samples. However, in spite of these limitations and sensitivities, 
Table 5 Results of the application of the evaluation guide to a practical case for liquefaction assessment.

\begin{tabular}{|c|c|c|c|c|}
\hline \multirow[t]{2}{*}{ Conditions } & \multirow[t]{2}{*}{ Item } & \multicolumn{3}{|c|}{ Evaluation } \\
\hline & & Condition to be checked & $\begin{array}{l}\text { Fulfilled or Not } \\
\text { fulfilled }\end{array}$ & $\begin{array}{l}\text { Potential of } \\
\text { Liquefaction }\end{array}$ \\
\hline$\overline{\text { Condition \#1 }}$ & 1 & $a \geq 0.13$ & 1 & \multirow{10}{*}{$\begin{array}{l}P Q=4.5 / 5=90 \% \\
\quad(\text { Equation } 4)\end{array}$} \\
\hline Condition \#2 & 2 & Saturated $(S \geq 95 \%)$ & 1 & \\
\hline \multirow[t]{3}{*}{ Condition \#3 } & 3.1 & $\begin{array}{l}0.05 \leq \mathrm{D} 15 \leq 0.44 \text { and } 0.08 \leq \mathrm{D} 50 \leq 0.70 \\
\text { and } 0.14 \leq \mathrm{D} 85 \leq 1.2\end{array}$ & 1 & \\
\hline & & $\begin{array}{l}0.014 \leq \mathrm{D} 15 \leq 0.05 \text { and } 0.02 \leq \mathrm{D} 50 \leq 0.08 \\
\text { and } 0.032 \leq \mathrm{D} 85 \leq 0.14\end{array}$ & & \\
\hline & 3.2 & $\begin{aligned} 0.44 & \leq \mathrm{D} 15 \leq 1.4 \text { and } 0.70 \leq \mathrm{D} 50 \leq 1.9 \text { and } \\
1.2 & \leq \mathrm{D} 85 \leq 3.5\end{aligned}$ & & \\
\hline \multirow[b]{2}{*}{ Condition \#4 } & 4.1 & $0 \leq \mathrm{N} \leq 20$ & & \\
\hline & 4.2 & $20<\mathrm{N} \leq 30$ & 0.5 & \\
\hline \multirow{3}{*}{ Condition \#5 } & 5.1 & $H_{2} \geq H_{1}$ and $H_{1} \leq 3.0 \mathrm{~m}$ & 1 & \\
\hline & 5.2 & $H_{2} \geq 0.67 H_{1}$ and $H_{1} \leq 6.0 \mathrm{~m}$ & & \\
\hline & 5.3 & $H_{2} \geq 0.47 H_{l}$ and $H_{l} \leq 8.5 \mathrm{~m}$ & & \\
\hline & & & Total $=4.5$ & \\
\hline
\end{tabular}

Table 6 Particle size distribution of soil samples from three different boreholes.

\begin{tabular}{cccc}
\hline \multirow{2}{*}{ Grain Size $(\mathrm{mm})$} & \multicolumn{3}{c}{ Percentage Finer $(\%)$} \\
\cline { 2 - 4 } & Borehole 2 & Borehole 3 & Borehole 9 \\
\hline 14 & 100.00 & & 100.00 \\
5 & 99.19 & 100.00 & 98.68 \\
2.5 & 94.11 & 98.71 & 96.44 \\
1.25 & 88.73 & 96.88 & 92.00 \\
0.63 & 83.34 & 94.26 & 86.48 \\
0.32 & 78.03 & 91.48 & 74.69 \\
0.16 & 64.07 & 81.11 & 18.19 \\
0.08 & 27.57 & 27.19 & 9.00 \\
\hline
\end{tabular}

Table 7 Results of the application of Prakash's method to the site of the practical case (at three different locations).

\begin{tabular}{ccccccccc}
\hline & Borehole 2 & \multicolumn{3}{c}{ Borehole 3 } & \multicolumn{3}{c}{ Borehole 9 } \\
\hline $\begin{array}{c}\text { Depth } \\
(\mathrm{m})\end{array}$ & $\tau_{c r}(\mathrm{kPa})$ & $\tau_{a v}(\mathrm{kPa})$ & $\begin{array}{c}\text { Depth } \\
(\mathrm{m})\end{array}$ & $\tau_{c r}(\mathrm{kPa})$ & $\tau_{a v}(\mathrm{kPa})$ & $\begin{array}{c}\text { Depth } \\
(\mathrm{m})\end{array}$ & $\tau_{c r}(\mathrm{kPa})$ & $\tau_{a v}(\mathrm{kPa})$ \\
\hline 0.61 & 1.349 & 1.207 & 0.61 & 1.250 & 1.215 & 0.61 & 1.233 & 1.1986 \\
1.22 & 2.791 & 2.496 & 1.22 & 2.466 & 2.397 & 1.22 & 2.433 & 2.364 \\
1.83 & 4.352 & 3.891 & 1.83 & 3.751 & 3.645 & 1.83 & 3.700 & 3.596 \\
2.44 & 5.200 & 5.199 & 2.44 & 4.761 & 5.176 & 2.44 & 4.719 & 4.885 \\
3.05 & 6.013 & 6.687 & 3.05 & 5.698 & 6.848 & 3.05 & 5.603 & 6.506 \\
3.66 & 6.632 & 7.839 & 3.66 & 6.051 & 7.791 & 3.66 & 5.819 & 7.3258 \\
4.27 & 7.067 & 8.965 & & & & 4.27 & 7.134 & 9.323 \\
& & & & & & 4.88 & 8.207 & 11.091 \\
& & & & & & 5.49 & 9.474 & 13.042 \\
& & & & & & 6.10 & 9.140 & 13.470 \\
\hline
\end{tabular}

the experiments performed have provided useful information on the identification and assessment of these three types difficult soils, and justifications of this general statement are given in the foregoing sections.

\section{CONCLUSION}

The aim of this investigation was the assessment and identification of three types of difficult soils, namely collapsible soils, expansive soils, and liquefiable soils. A parametric study was conducted in order to investigate the influence of some soil parameters on wetting-induced collapse strain, wetting-induced free swelling, and soil liquefaction susceptibility. The main conclusions drawn from this investigation are summarized as follows:

1. The wetting-induced collapse strain is inversely proportional to the dry unit weight and degree of 
saturation. The relationship between collapse strain and dry unit weight is linear, whereas for the degree of saturation, it is exponential. Furthermore, the curves representing the variation of wetting-induced collapse strain with clay content, equivalent diameter, and chemical composition (i.e., $\mathrm{CaO}$ and $\mathrm{Al}_{2} \mathrm{O}_{3}$ ) have the shape of a symmetrical bell curve, called a Gauss curve. The collapse strain varies linearly with the inundating stress. The wetting-induced collapse strain of a soil under any applied stress can be considered as the difference between the consolidation strains of the soil in saturated and unsaturated states. The critical dry unit weight $\left(\gamma_{d}\right)$ and degree of saturation $\left(S_{r}\right)$ above which no collapse occurs are $\gamma_{d}>17.2 \mathrm{kN} / \mathrm{m}^{3}$ and $S_{r}>55 \%$. Also, the maximum values of wetting-induced collapse strain of soils are reached when the clay content $C=17 \%$, equivalent $D_{e}=0.0186 \mathrm{~mm}$, or the percentage of $\mathrm{CaO}$ is $53.5 \%$ and that of $\mathrm{Al}_{2} \mathrm{O}_{3}$ is $8.7 \%$. An empirical relationship was developed for the prediction of wetting-induced collapse strain (Equation 14).

2. The wetting-induced free swelling increases along with dry unit weight, plasticity index, clay content, or the ratio $\sigma^{\prime} / P_{a}$. Also, wetting-induced free swelling decreases when moisture content or shrinkage index increases, whereas it increases when liquidity index decreases. The variation of the wetting-induced free swelling with any of these parameters is characterized by an exponential function. Similarly, to collapse strain, an empirical expression was developed for predicting the wetting-induced free swelling of clays (Equation 22).

3. A new procedure for the assessment of liquefaction of granular soils, based on a rapidly performed index and parameters, is proposed (Table 2). The suggested procedure is concerned with a qualitative and quantitative evaluation to assess the susceptibility to liquefaction of a given soil. The proposed method is mainly composed of five different conditions. Quantitatively, a soil in a site is classified as liquefiable if the maximum acceleration at the ground surface is greater than 0.13 , its degree of saturation $S \geq 95 \%$, the standard penetration test index $N \leq 20$, and the thickness of the deposit satisfies one of the following conditions: $H_{2} \geq H_{1}$ and $H_{1} \leq 3.0 \mathrm{~m}$ (for $a=0.2), H_{2} \geq 0.67 H_{l}$ and $H_{1} \leq 6.0 \mathrm{~m}$ (for $a=0.3$ ), and $H_{2} \geq 0.47 H_{1}$ and $H_{1} \leq 8.5 \mathrm{~m}(a=0.4$ to 0.5$)$, where $H_{2}$ is the thickness of the evaluated deposit and $H_{1}$ is the thickness of the soil at the ground surface. Furthermore, a relationship was developed in order to compute the potential for liquefaction $(P Q)$ as a percentage (Equation 23).

\section{REFERENCES}

Adnan, B.A. and Erdil, T.R.: 1992, Evaluation and control of collapsible soils. J. Geotech. Eng., 118, 10, 14911504.
ASTM D4546: 2003, Standard test methods for onedimensional swell or settlement potential of cohesive soils. West Conshohocken, PA: ASTM.

ASTM D-5333: 2003, Standard test method for measurement of collapse potential of soils (Withdrawn 2012). ASTM International.

Ayadat, T. and Belouahri, B.: 1998, Migration of fine size particles as a collapse mechanism of soils. Revue Française de Géotechnique, 83, 73-83.

Ayadat, T. and Hanna, A.M.: 2007a, Identification of collapsible soil using the Fall Cone apparatus. Geotech. Test. J., ASTM, 30, 4.

DOI: $10.1520 /$ GTJ14193

Ayadat, T. and Hanna, A. M.: 2007b, Prediction of collapse behaviour in soil. Eur. J. Civ. Eng., 11, 5. DOI: 10.1080/17747120.2007.9692947

Ayadat, T., Abbeche, Kh. and Hanna, A.M.: 2007c, Assessment of some factors affecting soil collapse behaviour. OttawaGeo Conference, 21-24 October.

Ayadat, T. and Hanna, A.M.: 2011, Assessment of soil collapse prediction methods. International Journal of Engineering-Transactions B: Applications, 25, 1, 19 26. DOI: 10.5829 /idosi.ije.2012.25.01b.03

Ayadat, T.: 2017, Case study: Foundation design in liquefiable site. Int. J. Eng. Res. Appl., 7(1, Part 1), 612. DOI: $10.9790 / 9622-0701010612$

Baziar, M.H. and Esna-Ashari, M.: 2004, Evaluation of liquefaction potential of silty sand using laboratory frozen sample and CPT results. Int. J. Civ. Eng., Iranian Society of Civil Engineers, 2004, 2, 3, 164172.

Baziar, M.H. and Jafarian, Y.: 2007, Assessment of liquefaction triggering using strain energy concept and ANN model, capacity energy. Soil Dyn. Earthq. Eng., 27, 1056-1072. DOI: 10.1016/j.soildyn.2007.03.007

Baziar, M. H. and Nilipour, N.: 2003, Evaluation of liquefaction potential using CPT and neural network. Soil Dyn. Earthq. Eng., 23, 631-635. DOI: $10.1016 / \mathrm{S} 0267-7261(03) 00068-\mathrm{X}$

Bigdeli, A.: 2018, Evaluation and control of collapsible Soils in Okanaganthompson region. Ph.D. Thesis, College of Graduate Studies, University of British Columbia.

Bigdeli, A. and Siddiqua, S.: 2016, Assessment and analysis of factors influencing the collapse. 69th Canadian Geotechnical Conference. Vancouver.

Blake, T. F.: 1997, Formula (4), summary report of proceedings of the NCEER Workshop on Evaluation of Liquefaction Resistance of Soils. Youd, T. L. and Idriss, I. M., eds., Technical Report NCEER, 97-0022.

Boudaghpour, S.: 2016, The study based on collapsible soils and their collapse potentials in Semnan Desert Area in Iran. IJSER, 7, 12, 546-555. DOI: 10.14299/ijser.2016.12.005

Booth, A.R.: 1975, The factors influencing collapse settlement in compacted soils. Proc. 6th Reg. Conf. for Africa on SMFE, Durban, South Africa, 57-63. DOI: 10.1016/0148-9062(75)91225-5

Booth, A.R.: 1977, Collapse settlement in compacted soils. CSIR Research Report 324, NITRR Bulletin 13, Pretoria, South Africa.

Bowles, J.E.: 1997, Foundation analysis and design. (5th ed.). McGraw-Hill.

Cox, D.W.: 1978, Volume change of compacted clay fill. ICE Conf. on Clay Fills, 79-86. DOI: $10.1680 / \mathrm{cf} 1979.00698 .0009$

Derriche, Z. and Kebaili, M.: 1998, Prediction of swelling of In-Aménas clays. Bulletin des Laboratoires des Ponts et Chaussées, France, 218, 15-23, (in French). 
Diana, W., Widianti, A, Hartono, E. and Muntohar, A. S.: 2018, Predicting heave on the expansive soils. MATEC Web of Conferences 195, 03008. DOI: $10.1051 /$ matecconf $/ 201819503008$

Erzin, Y.: 2004, Correlations for quick prediction of swell pressures. Electron. J. Geotech. Eng., 9.

Esna-Ashori., M. and Baziar, M.H.: 2004, Liquefaction resistance of silty sand based on laboratory sample and CPT results. Proc. 13th World Conf. on Earthquake Engineering, Vancouver, BC, Canada, 1-b, paper No. 1750.

Forouzan, A.J.: 2016, Prediction of swelling behaviour of expansive soils using modified free swell index, methylene blue and swell oedometer tests. The Graduate School of Natural and Applied Sciences, Middle East Technical University, M. Sc. Thesis.

Ganeshan, V.: 1982, Strength and collapse characteristics of a compacted residual soils. Thesis (M.E.), Asian Institute of Technology, Bangkok, Thailand.

Goh, A.T.C.: 1996, Neural-network modeling of CPT seismic liquefaction data. J. Geotech. Eng., 122, 1, 70 73. DOI: 10.1061/(ASCE)0733-9410(1996)122:1(70)

Holtz, W.G. and Gibbs, H.J.: 1956, Engineering properties of expansive clays. Transactions of ASCE, 121, 641663. DOI: 10.1061/TACEAT.0007325

Huang, C., Wang, X., Zhou, H. and Liang, Y.: 2019, Factors affecting the swelling-compression characteristics of clays in Yichang, China. Adv. Civ. Eng., 2019, 3, 113. DOI: $10.1155 / 2019 / 6568208$

Ishihara, K.: 1985, Stability of natural deposits during earthquakes. Proc. 11th Int. Conf. on Soil Mechanics and Foundation Engineering, San Francisco, 1, 321376.

Israr, J.: 2004, Development of correlations between index properties and swelling characteristics of swelling soils. M.Sc. Thesis, Department of Civil Engineering, University of Engineering and Technology Lahore, Pakistan.

Jenning, J.E. and Knight, K.: 1975, A guide to construction on or with materials exhibiting additional settlement due to 'collapse' of grain structure. Proc. 6th Regional Conf. for Africa on SMFE, Durban, South Africa, 1, 99-105. DOI: 10.1016/0148-9062(75)91203-6

Khemissa, M. and Mahamedi, A.: 2014, Cement and lime mixture stabilization of an expansive overconsolidated clay. Appl. Clay Sci., 95, 104-110. DOI: $10.1016 /$ j.clay.2014.03.017

Khemissa, M., Mekki, L. and Bakir, N.: 2008, Oedometric behaviour of expansive clays from M'sila (Algeria). SEC'2008: International Symposium on Drought and Construction. Presses du Laboratoire Central des Ponts et Chaussées, France, 229-234, (in French).

Komornik, A. and David, D.: 1969, Prediction of swelling pressure of clays. J. Soil Mech. Found. Div. ASCE, 95, $1,209-225$.

Kramer, S.L.: 1996, Geotechnical earthquake engineering. Prentice-Hall.

Lawton, E.C., Fragaszy, R.J. and James, H.H.: 1989, Collapse of compacted clayey sand. J. Geotech. Eng. Div., 115, 9, 1252-1267. DOI: 10.1061/(ASCE)0733-9410(1989)115:9(1252)

Lefebvre, G. and Ben Belfadhel, M.: 1989, Collapse at permeation for a compacted non-plastic till. 12th ICSMFE, Rio de Janeiro, 619-622.

Li, P., Vanapalli, S. and Li, T.: 2016, Review of collapse triggering mechanism of collapsible soils due to wetting. J. Rock Mech. Geotech. Eng., 8, 2, 256-274. DOI: 10.1016/j.jrmge.2015.12.002

Lin, B. and Cerato A.: 2011, Prediction of expansive soil swelling based on four micro-scale properties, 41, 1. DOI: 10.1007/s10064-011-0410-7

Lommler, J. and Bandini, P.: 2015, Characterization of collapsible soils. IFCEE 2015, 1834-1841.

Lutenegger, A.J. and Saber, R.T.: 1988, Determination of collapse potential of soils. Geot. Testing Jnl, GTJODJ, $11,3,173-178$.

Mahamedi, A. and Khemissa, M.: 2013, Cement stabilization of compacted expansive clay. TOJSAT: The Online Journal of Science and Technology, 3, 1, 33-38. http://www.tojsat.net/index.php/tojsat/article/view/77

Mahamedi, A. and Khemissa, M.: 2014, Stabilization of an expansive overconsolidated clay using hydraulic binders. HBRC Journal, 11, 1, 82-90. DOI: $10.1016 /$ j.hbrcj.2014.03.001

Markin, B.P.: 1969, Discussion on standard criteria of sag in loess soils. Soil Mech. Found. Eng., 2, 137.

Moss, R.E.S., Seed, R.B., Kayen, R.E., Stewart, J.P., Kiureghian, A. and Cetin, K O.: 2006, CPT based probabilistic and deterministic assessment of in situ seismic soil liquefaction potential. J. Geotech. Geoenviron. Eng., ASCE, 132, 8, 1032-1051. DOI: 10.1061/(ASCE)1090-0241(2006)132:8(1032)

Muntohar, A.S.: 2000, Prediction and classification of swelling clay soil. In Al-Rawas, A.A. and Goosen, M.F.A. (Eds.), Expansive soils: Recent advances in characterization and treatment, 25-36. Routledge.

Nayak, N.V. and Christensen, R.W.: 1971, Swelling characteristics of compacted expansive soils. Clay. Clay Miner., 19, 251-261. Pergamon Press. Printed in Great Britain.

NCEER: 1997, Proceedings of the NCEER Workshop on Evaluation of Liquefaction Resistance of Soils, Edited by Youd, T.L., Idriss, I.M. Technical Report, No. NCEER-97-0022, December 31.

Ping, L. and Vanapalli, S.K.: 2018, Simple method for prediction of the soil collapse behaviour due to wetting. Int. J. Geomech., 18, 11.

DOI: 10.1061/(ASCE)GM.1943-5622.0001285

Prakash, S.: 1981, Dynamic earth pressures, state of the art report. Int. Conf. Recent Advances on Geotechnical Earthquake Engineering and Soil Dynamics, St. Louis, Missouri, III, 993-1020.

Prusza, A. and Choudry, T.: 1979, Collapsibility of residual soils. Proc. 13th Congress on Large Dams, New Delhi, India, Q.49, 11.9, 117-130.

Ranganatham, M.B. V. and Satyanarayana, A.B.: 1965, A rational method of predicting potential for compacted expansive clays. Proc. 6th Int. Conf. on Soil Mechanics and Foundation Engineering, Montreal, 1, 92-96.

Rauch, A.F.: 1998, Personal communication. (As cited in Youd et al., 2001).

Robertson, P.K., Sully, J.P., Woeller, D.J., Lunne, T., Powell, J.J.M. and Gillespie, D.G.: 1992, Estimating coefficient of consolidation from piezocone tests. Canadian Geotechnical Journal, 29(4), 539-550. DOI: $10.1139 / \mathrm{t} 92-061$

Robertson, P.K. and Wride, C.E.: 1998, Evaluating cyclic liquefaction potential using the cone penetration test. Can. Geotech. J., 35, 3, 442-459.

DOI: $10.1139 / \mathrm{t} 98-017$ 
Olsen, R.S.: 1997, Cyclic liquefaction based on the cone penetrometer test. Proc. NCEER Workshop on Evaluation of Liquefaction Resistance of Soils, Tech. Rep. NCEER-97-0022, T. L. Youd and I. M. Idriss (Eds.). National Center for Earthquake Engineering Research, Buffalo, 225-276.

Samui, P. and Karthikeyan, J.: 2013, Determination of liquefaction susceptibility of soil: A least square support vector machine approach. Int. J. Numer. Anal. Methods Geomech., 37, 9,1154-1161. DOI: $10.1002 /$ nag. 2081

Seed, R.B., Cetin, K.O., Moss, R.E.S., Kammerer, A.M., Wu, J., Pestana, J.M., Riemer, M.F., Sancio, R.B., Bray, J.D., Kayen, R.E. and Faris, A.: 2003, Recent advances in soil liquefaction engineering: A unified and consistent framework. 26th Annual Spring Seminar of the ASCE Los Angeles Geotechnical Section, Long Beach, CA, 71pp.

Seed, R.B., Chang, S.W., Dickenson, S.E. and Bray, J.D.: 1997, Site-dependent seismic response including recent strong motion data. Proc. Special Session on Earthquake Geotechnical Engineering, XIV International Conf. on Soil Mechanics and Foundation Engineering, Hamburg, Germany, A.A. Balkema Publ., Sept. 6-12, 125-134.

Seed, H.B. and Idriss, I.M.: 1967, Soil liquefaction: Niigata earthquake. J. Soil Mech. Found. Div., ASCE, 93, 3, 83-108.

Seed, H.B. and Idriss, I.M.: 1971, Simplified procedure for evaluating soil liquefaction potential. J. Geotech. Eng. Div., ASCE, 97, 9, 1249-1273.

Seed, H.B., Idriss, I.M., and Arango, I.: 1983, Evaluation of liquefaction potential using field performance data. J. Geotech. Eng. Div., ASCE, 109, 3, 458-482. DOI: 10.1061/(ASCE)0733-9410(1983)109:3(458)

Seed, H.B. and Peacock, W.H.: 1971, Test procedures for measuring soil liquefaction characteristics. J. Soil Mech. Found. Div., ASCE, 97, SM8, 1099-1119.

Seed, H.B., Tokimatsu, K., Harder, L.F. and Chung, R.M: 1984, Influence of SPT procedures in soil liquefaction resistance evaluation. Rep. No. UCB/EERC-84/15, Earthquake Engineering Res. Ctr., Univ. of California, Berkeley, California.
Seed, H.B., Woodward, R.J. and Lungren, R.: 1962, Prediction of swelling potential for compacted clays. J. Soil Mech. Found. Div., 88, 3, 53-87. DOI: 10.1061/JSFEAQ.0000431

Skempton, A.W.: 1986, Standard penetration test procedures and the effects in sands of overburden pressure, relative density, particle size, aging and overconsolidation. Géotechnique, 36, 3, 425-447. DOI: 10.1680/geot.1986.36.3.425

Tokimatsu, K. and Uchida, A.: 1990, Correlation between liquefaction resistance and shear wave velocity. Soil Found., 30, 2, 33-42.

DOI: $10.3208 /$ sandf1972.30.2_33

Tsuchida, H.: 1970, Prediction and countermeasure against the liquefaction in sand deposits. Seminar at the Port and Harbor Research Institute.

Vijayvergiya, V.N. and Gazzhaly, Y.O.I.: 1973, Prediction of swelling potential for natural clays. Proc. 3rd Int. Conf. on Expansive Soils, Jerusalem, Jerusalem Academic Press, 1, 227-236.

Youd, T.L., Idriss, I.M., Andrus, R.D., Arango, I., Castro, G., Christian, J.T., Dobry, R., Finn, W.D.L., Harder Jr., L.F., Hynes, M.E., Ishihara, K., Koester, J.P., Liao, S.S.S., Marcuson III, W.F., Martin, G.R., Mitchel, J.K., Moriwaki, Y., Power, M.S., Robertson, P.K., Seed, R.B. and Stokoe, H.K.H.: 2001, Liquefaction resistance of soils: Summary report from the 1996 NCEER and 1998 NCEER/NSF Workshops on Evaluation of Liquefaction Resistance of Soils. J. Geotech. Geoenviron. Eng., ASCE, 127, 10, 817-833. DOI: 10.1061/(ASCE)1090-0241(2001)127:10(817) 
APPENDIX A

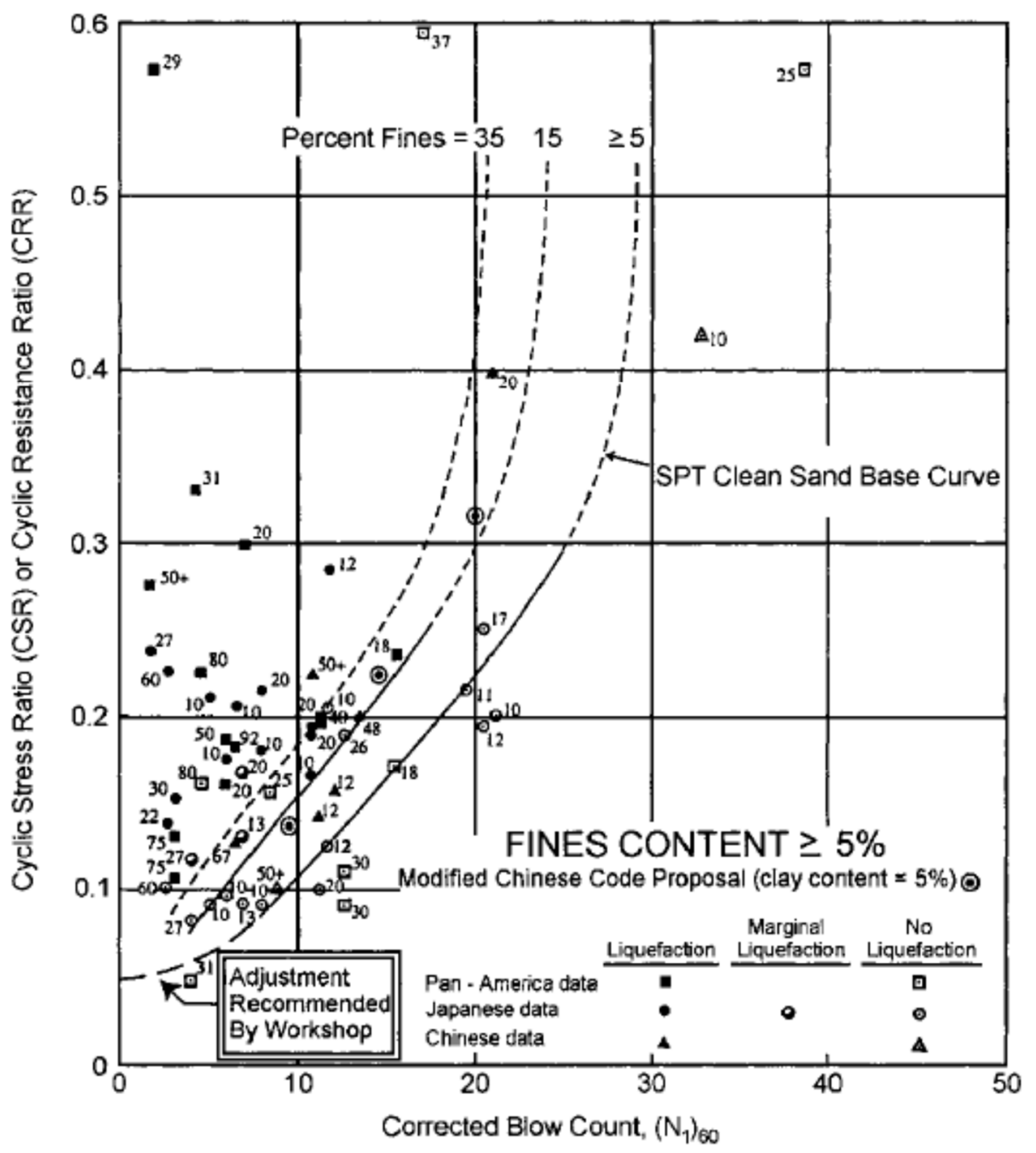

Fig. A1 SPT clean sand base curve for magnitude 7.5 earthquakes with data from liquefaction case histories (NCEER, 1997; Seed et al., 2003). 


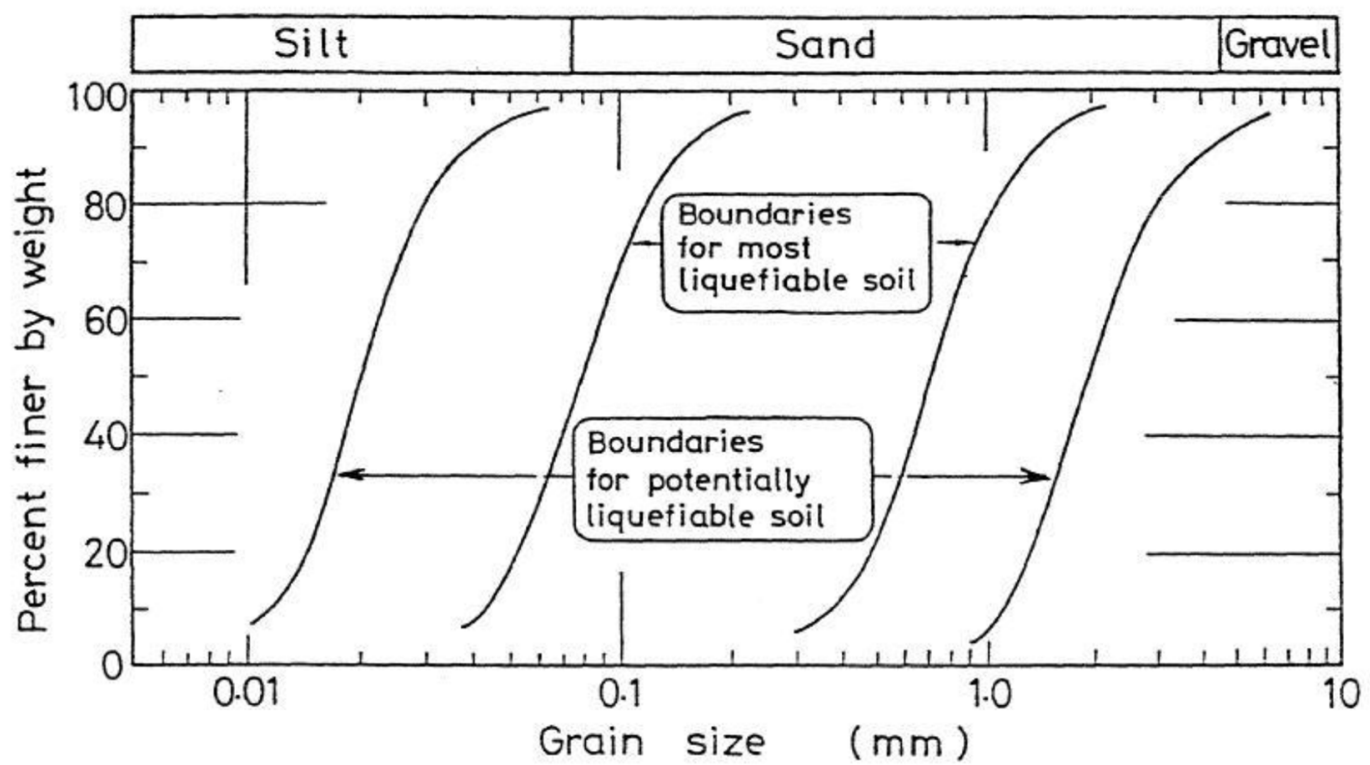

Fig. A2 Limits in the gradation curves separating liquefiable and non-liquefiable soils (Tsuchida, 1970).

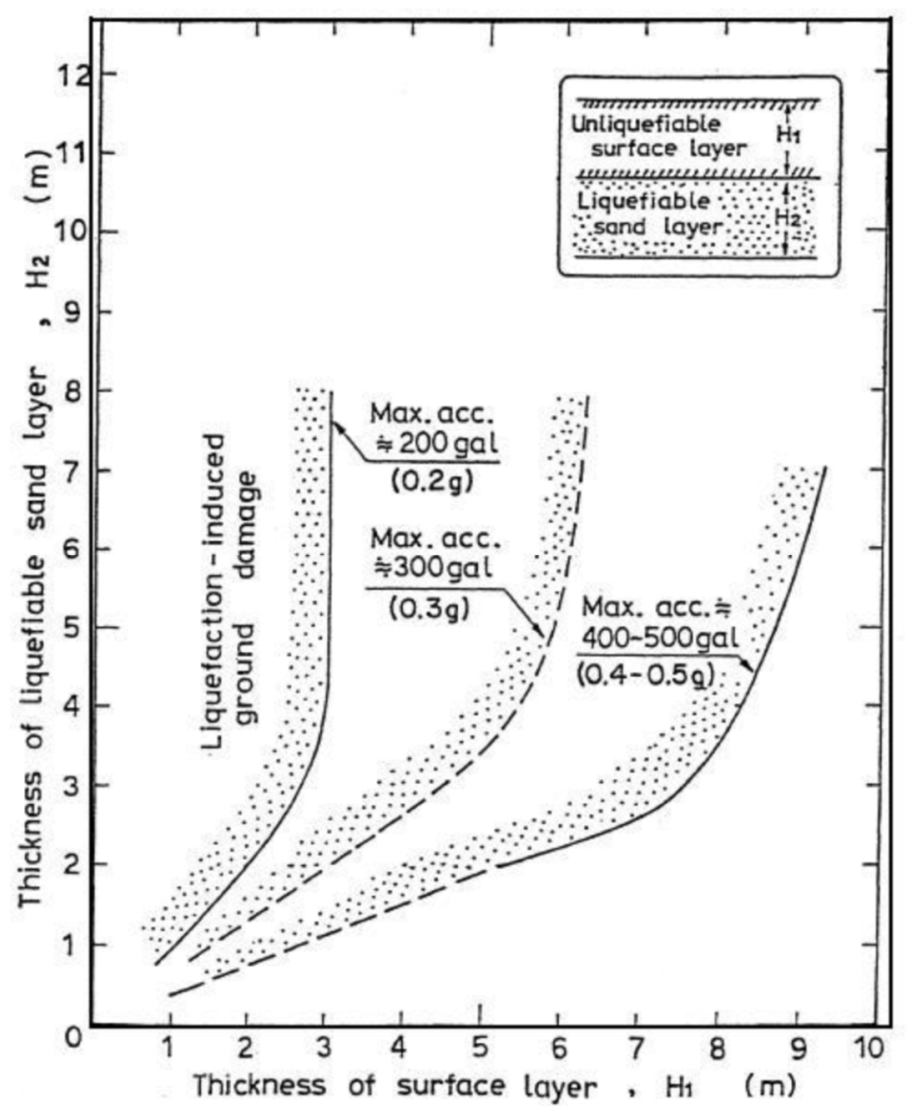

Fig. A3 Proposed boundary curves for site identification of liquefaction-induced ground damage (Ishihara, 1985). 